\title{
Pebble Morphometric Study of the Ogwashi-Asaba Formation at Ubakala and Environs in Southeastern Nigeria
}

\author{
Ogechukwu Caroline Onyemesili \\ Department of Geology, Chukwuemeka Odumegwu Ojukwu University, \\ PMB 02, Uli, Anambra State, .Nigeria \\ Chukwuemeka Frank Raluchukwu Odumodu \\ Department of Geology, Chukwuemeka Odumegwu Ojukwu University, \\ PMB 02, Uli, Anambra State, Nigeria
}

\begin{abstract}
Pebble morphometric study was carried out for the Ogwashi-Asaba Formation so as to understand its paleodepositional environment. The three axes; the long (1), the intermediate (i) and the short (s) were measured for the two sets of one hundred and forty (140) and one hundred and fifty (150) pebbles collected from two outcrops of the Ogwashi-Asaba Formation. Pebble form indices such as Maximum Projection Sphericity (MPSI), coefficient of flatness (FR \%), elongation ratio (ER) and oblate-prolate (OP) index were computed from these measurements. Roundness was estimated using Sames image sets. The mean values of the pebble form indices ranges from 49.78 to 52.02 for coefficient of flatness (FR \%). 0.71 to 0.73 for sphericity, 2.60 t0 3.53 for oblateprolate index, and 0.66 to 0.69 for elongation ratio. The calculated indices are suggestive of fluvial sedimentation for the Ogwashi-Asaba Formation. Bivariate plots of coefficient of flatness (FR \%) versus maximum projection sphericity index (MPSI) and plots of sphericity (MPSI) versus oblate-prolate index (OP) are also indicative of fluvial origin. Scatter plots of roundness versus elongation ratio shows that $100 \%$ of the pebbles are in a littoral field. Plots of bivariate parameters such as simple skewness versus simple standard deviation, and second moment skewness versus second moment standard deviation suggests the Ogwashi-Asaba Formation as a product of the fluvial depositional processes.
\end{abstract}

Keywords: Niger Delta Basin, Ogwashi-Asaba Formation, Pebble morphometry, Pebble Form indices.

DOI: $10.7176 /$ JNSR/9-6-06

Publication date:March $31^{\text {st }} 2019$

\section{Introduction}

Pebble morphometric and other granulometric analysis have been utilized in paleoenvironmental interpretation of several sedimentary basins in Nigeria and worldwide. Ephraim et al (2015) used pebble morphometric investigations to suggest that the Benin Formation as exposed at Nsie, in southeastern Nigeria were deposited by fluvial processes. Odumodu and Isreal (2014) combined pebble morphometric analysis, lithofacies interpretation and sand textural analysis to infer a fluvial depositional environment for the Ogwashi-Asaba Formation as exposed at Nnewi and environs. Odumodu (2014) also utilized pebble form indices as a paleoenvironmental reconstruction tool to provide evidence for the fluvial origin of the Benin Formation, outcropping along Atamiri River, in Uli, Anambra State. Other previous pebble based paleoenvironmental interpretations include the works of Odumodu (2013), Odumodu and Odumodu (2012), Odumodu and Ephraim (2007a, 2007b) and Nwajide and Hoque (1982).

Several outcrops of the Ogwashi-Asaba Formation occur at Ubakala, in the vicinity of Umuahia in Abia State of Nigeria. Jan Du Chene et al (1978) has previously on the basis of palynological study of lignite's; shales and clays samples, interpreted the Ogwashi-Asaba Formation as a swamp deposit. All previous paleoenvironmental studies utilizing pebbles and other granulometric materials did not consider the outcrops of Ogwashi-Asaba Formation outcropping at several localities around Umuahia. It is therefore necessary to evaluate these exposures so as to resolve its paleodepositional setting.

\subsection{Geological Background}

The study area lies within the Niger Delta Basin. The study area is located at Ubakala, near Umuahia as shown in Figure 1. The area is underlain by the Oligocene to Miocene Ogwashi-Asaba Formation, which was formerly known as the 'lignite series' (Parkinson, 1907; Simpson, 1954) or 'lignite group' (Wilson, 1925; Wilson and Bain, 1928; Du Preez, 1946; Okezie and Onuogu, 1985). Du Preez (1946) described the Ogwashi-Asaba Formation to consist of clays, sands, grits and seams of lignites alternating with grit clays. Umeji (2003) described the formation to be composed of sandstone, shales, carbonaceous shales and lignites.

Short and Stauble (1967) discussed the various diachronous units constituting the Niger Delta Basin to include the basal marine prodelta shales of the Akata Formation, which is overlain by the paralic sand-shale sequence of the Agbada Formation. The Agbada Formation is overlain by the continental sands and gravels of the Benin Formation. Short and Stauble (1967) considered the Imo Formation as the outcrop equivalent of the Akata 
Formation in the subsurface of the Niger Delta, and also regarded the Ameki Group (Ameki Formation and Nanka Sands) and the Ogwashi-Asaba Formation as being correlative to the Agbada Formation (Table 1).

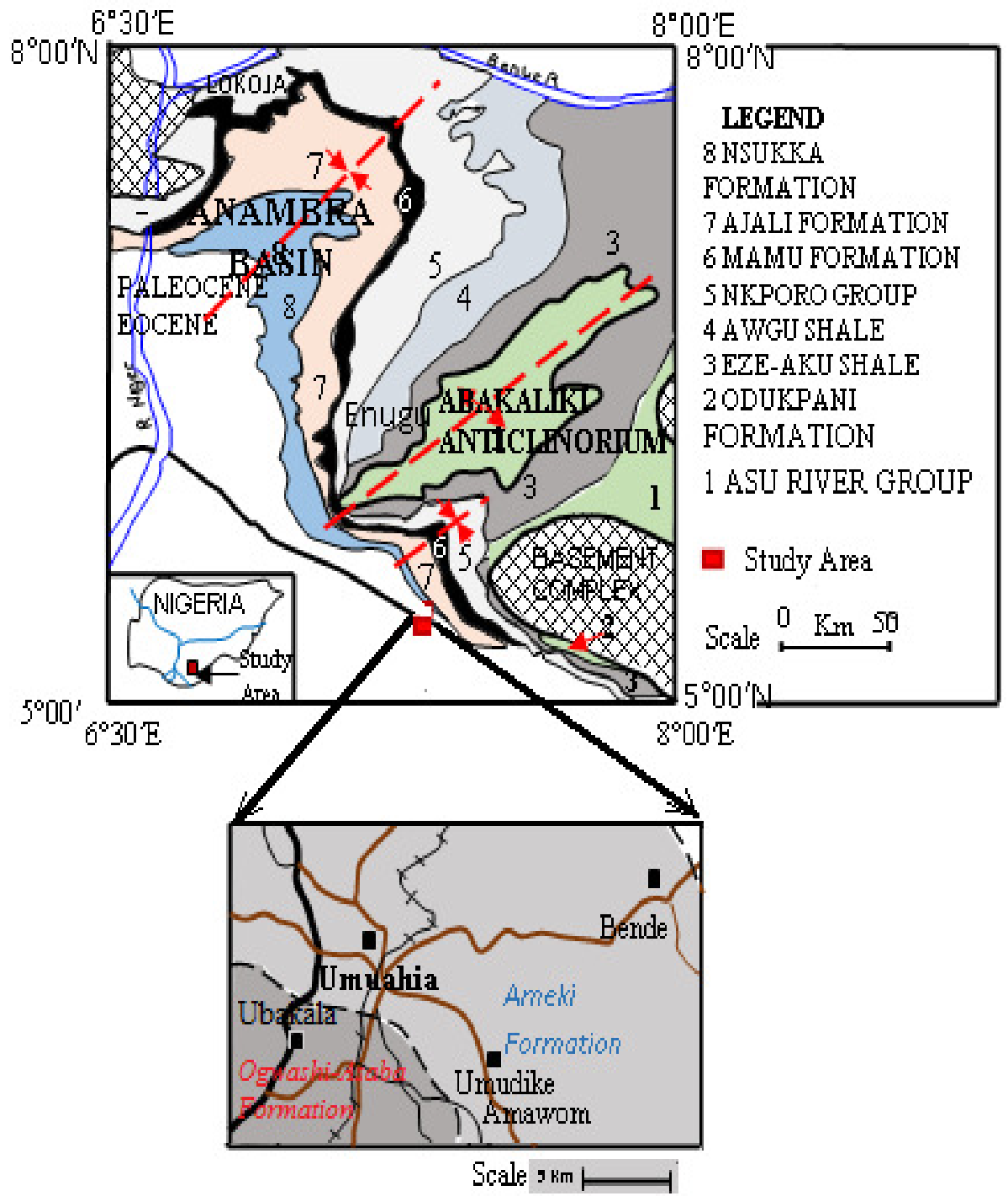

Fig. 1: Location map of the study area. Inset is the geologic map of southeastern Nigeria.

Table 1: Correlation of subsurface formations in the Niger Delta with outcrops (Short and Stauble, 1967; Avbovbo, 1978).

\begin{tabular}{lll}
\hline \multicolumn{1}{c}{ Age } & \multicolumn{1}{c}{ Surface } & \multicolumn{1}{c}{ Subsurface Niger Delta } \\
\hline Miocene - Recent & Benin Formation & Benin Formation \\
U. Eocene - Oligocene & Ogwashi-Asaba Formation & Upper Agbada Formation \\
Middle - Lower Eocene & Nanka Fm / Ameki Fm & Agbada Formation \\
Paleocene & Imo Formation & Akata Formation \\
\hline
\end{tabular}

\subsection{Sedimentary Facies}

Five outcrop sections of the Ogwashi-Asaba Formation were logged at some quarries and erosional cuts located at Ubakala near Umuahia, off Umuahia-Aba expressway at Location 1: Lat.: $5^{\circ} 30^{\prime} 53.8^{\prime \prime} \mathrm{N}$, Long.: $7^{\circ} 27^{\prime} 01.99^{\prime \prime} \mathrm{E}$, Location 2: Lat.: $5^{\circ} 30^{\prime} 54.65^{\prime \prime} \mathrm{N}$, Long.: $7^{\circ} 27^{\prime} 08.65^{\prime \prime} \mathrm{E}$, Location 3: Lat. 5 $20^{\prime} 54.25^{\prime \prime} \mathrm{N}$, Long.: $7^{\circ} 27^{\prime} 11.62^{\prime \prime} \mathrm{E}$, Location 4: Lat.: $5^{\circ} 32^{\prime} 50.58^{\prime \prime} \mathrm{N}$, Long.: $7^{\circ} 27^{\prime} 27.13^{\prime \prime} \mathrm{E}$, Location 5: Lat. 5³3'140.74”N, Long.: 7²6'56.67"'E (Fig. $2 \mathrm{a}-\mathrm{e})$. The lithology consists of fine, medium and coarse grained sandstones, sandy clay and carbonaceous shales. Six sedimentary facies were observed in the studied area, which include (i) coarse to very coarse grained massive sandstones. In this facies, the sedimentary fabric consist of pebbly massive sandstone beds, in which many pebbles are embedded in a matrix of coarse grained to very coarse grained sandstones. This facies are very prominent at 
Location 6. (ii) coarse grained bioturbated sandstones. In this facies, the sedimentary fabric consists of a matrix of coarse grained bioturbated sandstones embedded with very few pebbles. Sedimentary structures present are planar crossbeds and Ophiomorpha burrows (Fig. 3a). This facies were observed at location 1 and 6. (iii). medium to coarse grained bioturbated sandstone facies. The lithology in this facies consists of medium to coarse grained bioturbated sandstones. The trace fossil present is Ophiomorpha burrows. It is also planar crossbedded, with paleocurrents pointing southwards. This facies were observed at Location 6. (iv) Planar cross bedded sandstone facies. In this facies, lithology consists of planar crossbedded sandstones. The thickness of this facies thins down southwards. This facies were observed at Location 3. (vi) Lignitiferous clays. The lithology in this facies consists of massive clayey beds containing very thin lenses of sands and some thin bands of lignite. This facies occurs at Location 3. (vii) Fissile shales. This consists of beds of dark grey laminated and carbonaceous shales, often with some lenses of sand in places.

\subsection{Materials and Methods}

The methodology involved lithologic logging of quarries and erosional cuts where the pebbly units were encountered. The pebbles were carefully collected from the beds and latter selected so as to exclude cracked or broken ones. A total of 140 and 150 pebbles were selected from the several pebbles collected from two locations 1 and 2. Pebbles selected were considered to be of isotopic constitution and of high resistant to wear. The venier caliper were used to measure the three mutually perpendicular (Long, L; Intermediate, I; Short, S) axis of the pebbles based on Krumbein (1941), Sneed and Folk (1958) and Dobkins and Folk (1970) technique. Other morphometric parameters were computed in an excel spreadsheet, using the values obtained from the measurement of the three axis (Table 2). The pebbles were arranged into half-phi size group using the intermediate axes (Table 3 ), which is known as the 'sieve diameter' for pebbles (Tucker, 1981). Roundness of pebbles was evaluated using a visual comparison chart of images as compiled by Sames (1966) and used by Sneed and Folk (1958).

Table 2: Pebble Morphometric Indices used for the study

\begin{tabular}{|l|l|l|}
\hline Morphometric Indices & Formula & Author \\
\hline $\begin{array}{l}\text { Flatness ratio } \\
\text { Coefficient of flatness }\end{array}$ & $\begin{array}{l}\mathrm{S} / \mathrm{L} \\
\mathrm{S} / \mathrm{L} * 100\end{array}$ & Lutig, 1962 \\
\hline Elongation ratio & $\mathrm{I} / \mathrm{L}$ & Lutig, 1962 \\
\hline Maximum projection sphericity & $\left(\frac{S^{2}}{L I}\right)^{1 / 3}$ & Sneed and Folk, 1958 \\
\hline Oblate - prolate index & $10\left[\frac{L-I}{L-S}-0.50\right] S / L$ & Dobkins and Folk, 1970 \\
\hline Roundness (\%) & Visual Estimation & Sames (1966) \\
\hline
\end{tabular}


A.

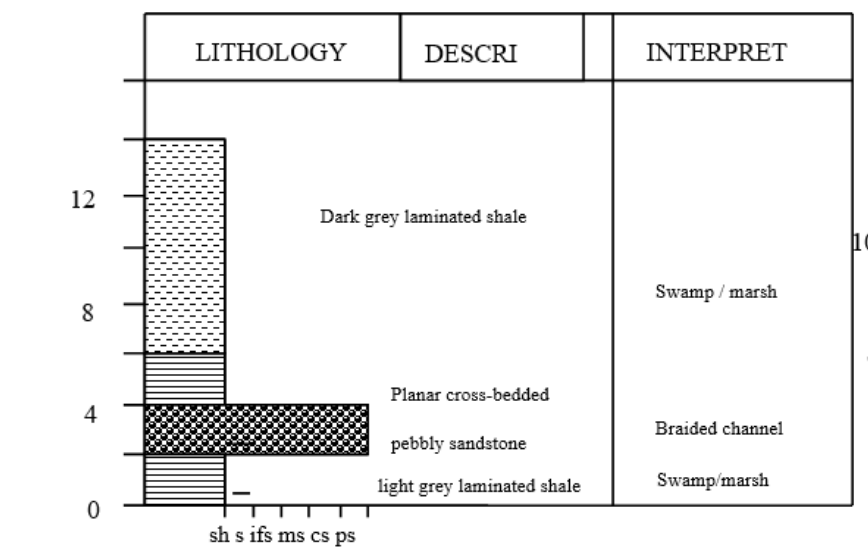

B.
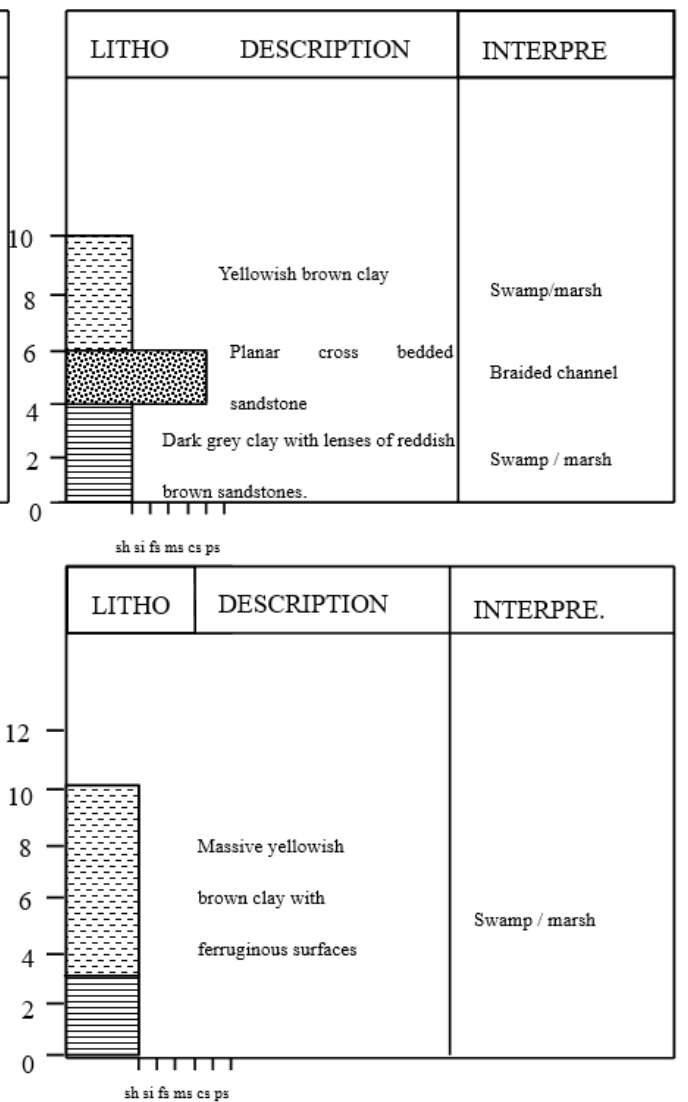

D.

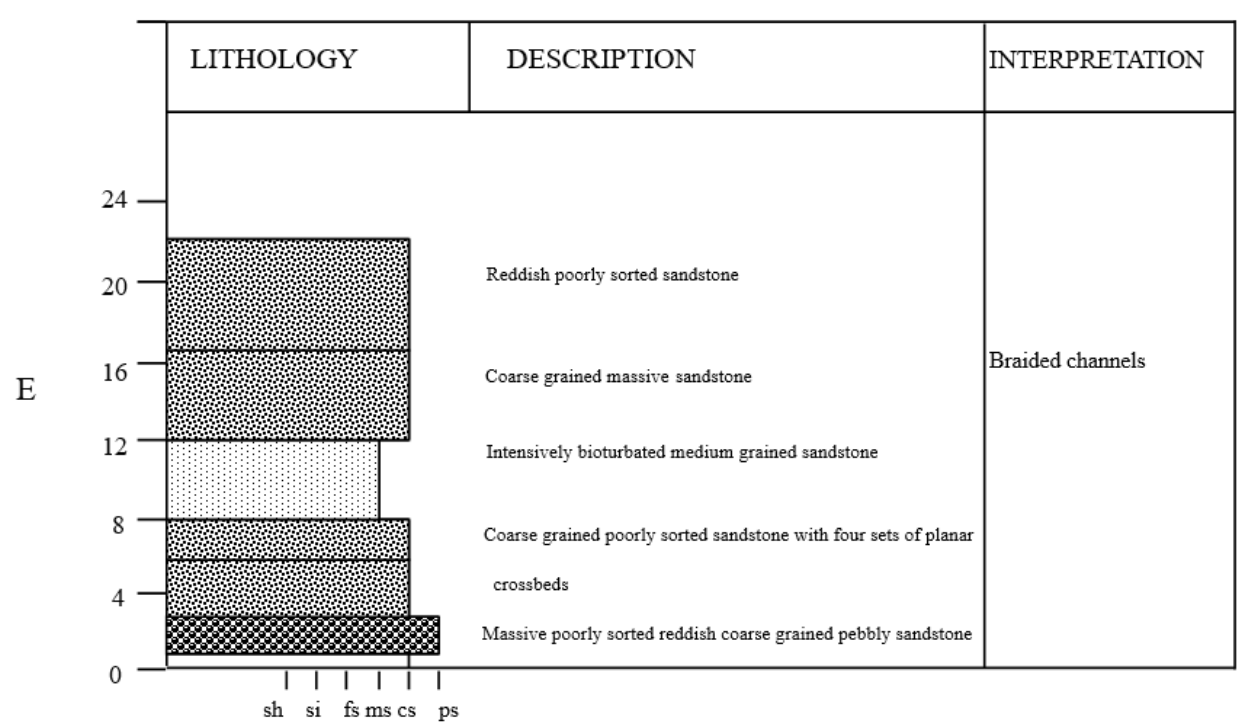

Fig. 2: Lithologs of outcrops of the Ogwashi-Asaba Formation studied 


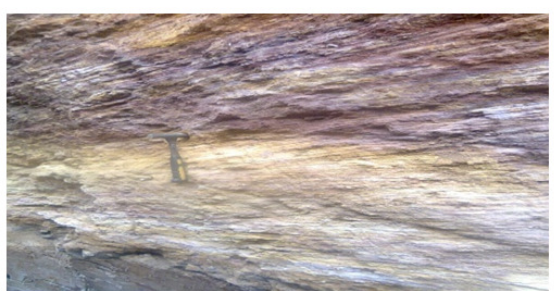

Fig. 3a: Planar cross beddings

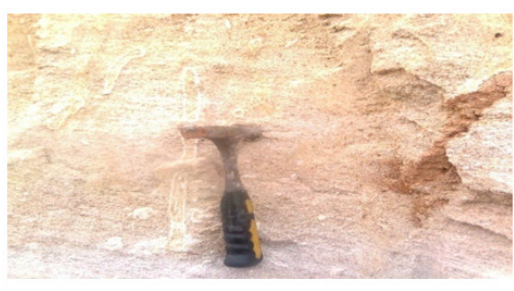

Fig. 3b: Ophiomorpha burrows

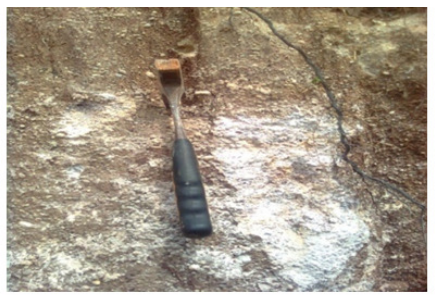

Fig. 3c; Pebbly beds

Table 3: Grain size scales for pebbles (modified from Tucker (1981)

$\left.\begin{array}{ll}\hline \boldsymbol{m} \boldsymbol{m} & \multicolumn{1}{c}{\text { Phi }} \\ 48-64 & >-5.5 \\ 32-48 & >-4.5 \\ 24-32 & >-4.0 \\ 16-24 & >-3.5 \\ 12-16 & >-3.0 \\ 8-12 & >-2.5 \\ 6-8 & >-2.0 \\ 4-6 & \text { Class Term }\end{array}\right\}$

Table 4. Statistical parameters of sandstones used in this study

\begin{tabular}{|c|c|c|}
\hline Statistical parameters & Formula & Author \\
\hline Mean ( $1^{\text {st }}$ Moment $)$ & $x=\sum f m \varphi / 100$ & $\begin{array}{c}\text { Friedman (1967, } \\
1979)\end{array}$ \\
\hline Standard Deviation or sorting $\left(2^{\text {nd }}\right.$ Moment & $\sigma=\sqrt{\sum f(m \varphi-x)}^{2} / 100$ & (1) \\
\hline Skewness ( $3^{\text {rd }}$ Moment) & $\alpha_{3}=\sum f(m \varphi-x)^{3} / 100 \sigma^{3}$ & “ \\
\hline Kurtosis ( $4^{\text {th }}$ Moment $)$ & $\sum f(m \varphi-x)^{4} / 100 \sigma^{4}$ & “" \\
\hline Graphic Mean & $1 / 3(\varphi 16+\varphi 50+\varphi 84)$ & Folk, 1974 \\
\hline Inclusive (graphic) skewness & $\frac{1}{2} \frac{\phi 16+\phi 84-2 \phi 50}{\phi 84-\phi 16}+\frac{\phi 5+\phi 95-2 \phi 50}{\phi 95-\phi 5}$ & ،, \\
\hline Inclusive (graphic) standard deviation & $\sigma_{1}=\varphi 84-\varphi 16 / 4+\varphi 95-\varphi 5 / 6.6$ & “6 \\
\hline
\end{tabular}

1.1.2 Textural Parameters

Textural parameters of sandstone samples of the Ogwashi-Asaba Formation were evaluated using conventional sieving procedures (Folk, 1974). First of all, the samples were carefully disaggregated. About 50 gram of each sample was sieved using one phi sieve interval. The sieving time used is about 15 minutes. The plotted cumulative probability curves were then used to determine the critical percentiles $(5 \phi, 16 \phi, 25 \phi, 50 \phi, 84 \phi$ and $95 \phi$. The calculated textural parameters include graphic mean, $(\mathrm{Mz})$, inclusive graphic skewness $\left(\mathrm{S}_{\mathrm{k}}\right.$ ), inclusive graphic standard deviation $\left(\sigma_{\mathrm{o}}\right)$ and moment mean grain size $\left(\mathrm{m}_{1}\right)$, moment standard deviation $\left(\mathrm{m}_{\sigma}\right)$, moment skewness $\left(\mathrm{m}_{3}\right)$ and moment kurtosis (Table 4). These parameters were employed in bivariate plots for paleoenvironmental reconstructions (Figs. 4a-b, 5a-b, 6a-b).

\subsection{Results}

The computed form data and roundness data are presented in Tables 5 and 8a-b whereas a summary of the morphometric indices, characteristics and environmental implications are given in Table 6 . The results of pebble morphometric analysis (Table 5) suggest that the mean values for maximum projection sphericity range from 0.71 to 0.73 . The mean values of the oblate-prolate index range from 2.60 to 3.53 . The mean values of the coefficient flatness range from 49.78 to 52.02 . The form indices are also displayed using the graphic method by plots of coefficient of flatness versus sphericity (Fig. 4a-b) (Stratten, 1974), and plots of sphericity versus oblate-prolate index (Fig.5a-b) (Stratten, 1974), and plots of roundness versus elongation ratio (Fig. 6 a-b) (Dobkins and Folk, 1970). 
Table 5: Pebble Form Indices for the Ogwashi - Asaba Formation pebbles Coefficient of flatness Sphericity Oblate -Prolate Index

\begin{tabular}{|c|c|c|c|c|c|c|c|}
\hline & $\mathrm{n}$ & $x$ & $\mathrm{~s}$ & $\times$ & $\mathrm{s}$ & $x$ & $\mathrm{~s}$ \\
\hline \multicolumn{8}{|c|}{$\begin{array}{l}\text { (A) Combined form Data for pebbles larger than }-2.0 \text { phi } \\
\text { Locality }\end{array}$} \\
\hline Location 1 & 140 & 52.02 & 33.50 & 0.73 & 0.22 & 3.53 & 4.47 \\
\hline Location 2 & 150 & 49.78 & 12.14 & 0.71 & 0.10 & 2.60 & 4.40 \\
\hline \multicolumn{8}{|c|}{ (B) Form Data for Location 1} \\
\hline \multicolumn{8}{|c|}{ Size (Phi Units) } \\
\hline$>-3.5$ & 23 & 64.748 & 78.986 & 0.843 & 0.520 & 6.943 & 4.472 \\
\hline$>-4.0$ & 85 & 50.414 & 11.647 & 0.719 & 0.080 & 3.196 & 4.049 \\
\hline$>-4.5$ & 25 & 48.948 & 8.775 & 0.709 & 0.077 & 3.194 & 3.243 \\
\hline$>-5.0$ & 6 & 42.235 & 8.217 & 0.615 & 0.073 & -2.221 & 4.909 \\
\hline$>-5.5$ & 1 & 31.461 & - & 0.512 & - & -3.778 & - \\
\hline \multicolumn{8}{|c|}{ (C) Form Data for Location 2} \\
\hline$>-3.5$ & 23 & 44.964 & 12.125 & 0.703 & 0.093 & 6.664 & 3.588 \\
\hline$>-4.0$ & 100 & 50.856 & 11.764 & 0.714 & 0.096 & 2.147 & 3.911 \\
\hline$>-4.5$ & 24 & 50.710 & 12.174 & 0.703 & 0.115 & 0.619 & 4.887 \\
\hline$>-5.0$ & 3 & 42.690 & 20.050 & 0.636 & 0.156 & 2.634 & 1.872 \\
\hline
\end{tabular}

Table 6: Roundness indices for the pebbles from the Ogwashi - Asaba Formation

(A) Combined roundness indices for pebbles of different sizes for the five locations studied

\begin{tabular}{cccc}
\hline $\begin{array}{c}\text { Roundness } \\
\text { Location }\end{array}$ & $\mathrm{n}$ & $\times$ & $\mathrm{s}$ \\
\hline 1 & 140 & 0.798 & 0.083 \\
2 & 150 & 0.805 & 0.098
\end{tabular}

(B) Roundness indices for different fractions at the five locations studied

\begin{tabular}{cccccccc}
\cline { 2 - 6 } Phi Class & $\mathrm{n}$ & $\mathrm{x}$ & & $\mathrm{s}$ & $\mathrm{n}$ & \multicolumn{1}{c}{$\mathrm{s}$} & $\mathrm{x}$ \\
\hline$>-3.5$ & 23 & 0.80 & 0.10 & 23 & 0.83 & 0.07 \\
$>-4.0$ & 85 & 0.81 & 0.06 & 100 & 0.80 & 0.09 \\
$>-4.5$ & 25 & 0.77 & 0.10 & 24 & 0.82 & 0.11 \\
$>-5.0$ & 6 & 0.80 & 0.11 & 3 & 0.71 & 0.07 \\
$>-5.5$ & 1 & 0.93 & - & - & - & - \\
\hline
\end{tabular}

(C) Combined roundness indices of all pebbles for the different size fractions

Roundness

\begin{tabular}{clcc} 
Phi Class & $\mathrm{n}$ & $\times$ & $\mathrm{s}$ \\
\hline$>-3.5$ & 1 & 0.960 & - \\
$>-4.0$ & 8 & 0.911 & 0.013 \\
$>-4.5$ & 65 & 0.775 & 0.140 \\
$>-5.0$ & 44 & 0.796 & 0.153 \\
$>-5.5$ & 2 & 0.850 & -
\end{tabular}

$\times$ is ths mean roundness; $\mathrm{s}$ is the standard deviation of the observations, $\mathrm{n}=$ number of samples;

Table 7: Summary of environmental diagnosis for pebble morphometric analysis for Ogwashi-Asaba pebbles

\begin{tabular}{|l|ll|l|}
\hline Morphometric Indices & Characteristics & $\begin{array}{l}\text { Environmental } \\
\text { indications }\end{array}$ \\
\hline Coefficient of Flatness & Average values $52.02 \pm 33.5,49.78 \pm 12.14$ & Fluviatile \\
\hline Elongation Ratio & Average values $0.661 \pm 0.127,0.682 \pm 0.118$ & Fluviatile \\
\hline Maximum Projection Sphericity & Average value $0.73 \pm 0.22,0.71 \pm 0.10$ & Fluviatile \\
\hline Oblate-prolate index & Average values $3.53 \pm 4.47,2.60 \pm 4.40$ & Fluviatile \\
\hline Roundness \% & Average values $0.798 \pm 0.083,0.805 \pm 0.098$ & Fluviatile \\
\hline $\begin{array}{l}\text { Dominant pebble forms } \\
\text { Plot of coefficient of flatness versus } \\
\text { Maximum projection sphericity }\end{array}$ & $\begin{array}{l}\text { Elongate }(\mathrm{E})(29 \%), \text { Compact Elongate }(\mathrm{CE}=22 \%) \\
\text { Bladed }(\mathrm{B}=21 \%), \text { Compact Bladed }(\mathrm{CB}=14 \%)\end{array}$ & Fluviatile \\
\hline $\begin{array}{l}\text { Plot of Roundness versus elongation } \\
\text { ratio }\end{array}$ & $100 \%$ littoral & Fluviatile \\
\hline Plot of OP index versus Sphericity & Cluster in fluviatile field & Littoral \\
\hline
\end{tabular}



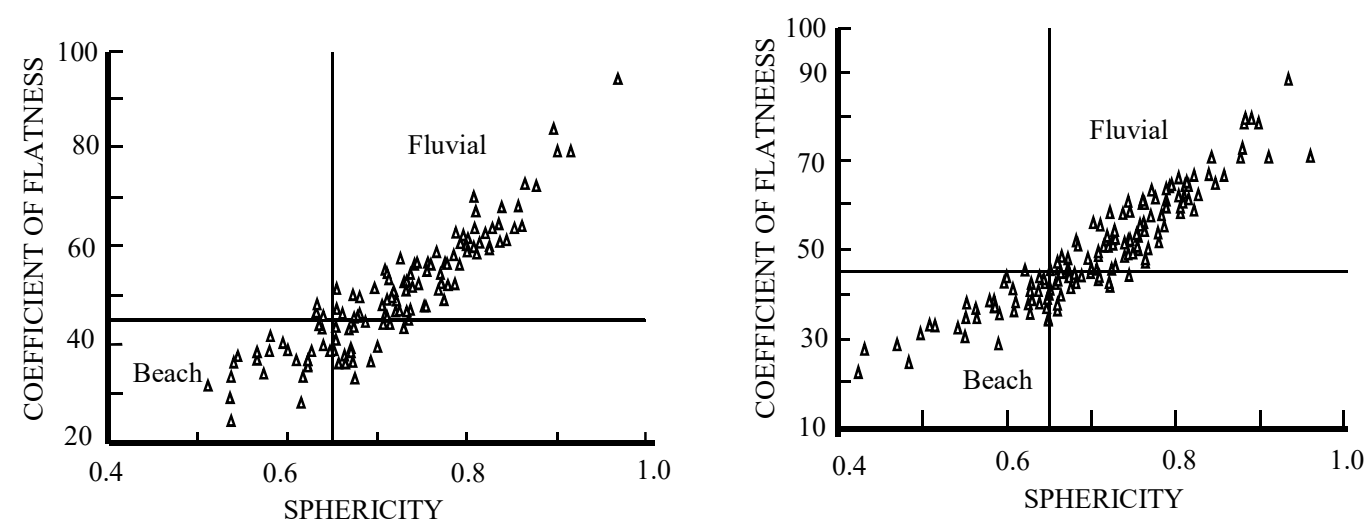

Fig. 4: Plot of coefficient of flatness against sphericity for pebbles of the Ogwashi-Asaba Formation at Location 1 and Location 2.
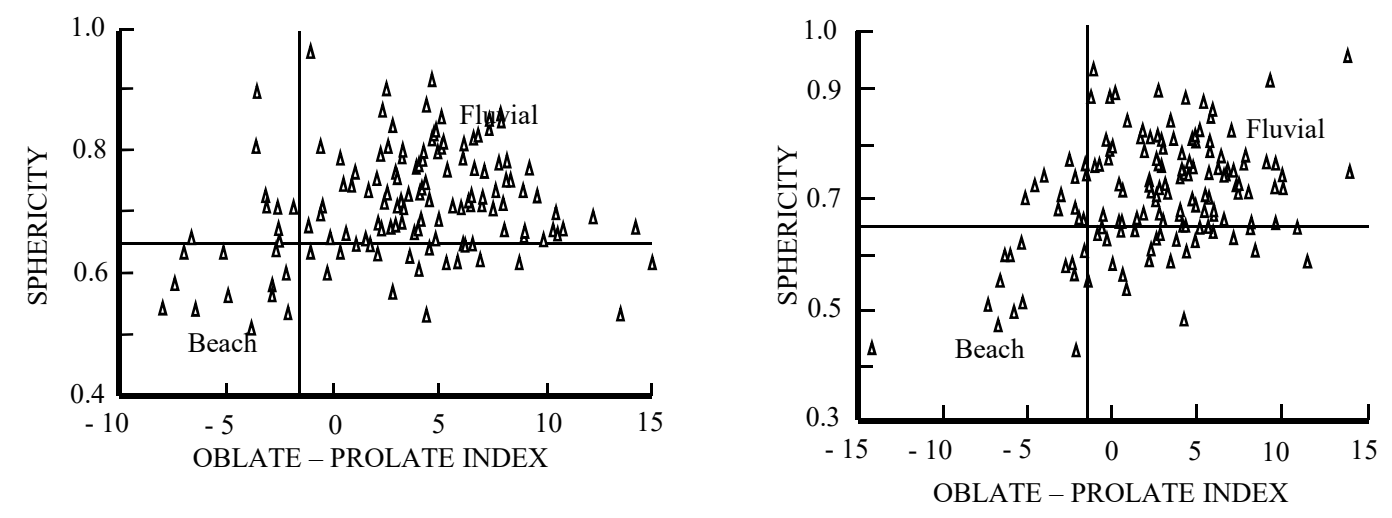

Fig. 5: Plot of Sphericity against oblate-prolate index for pebbles of the Ogwashi-Asaba Formation at Location 1 and Location 2
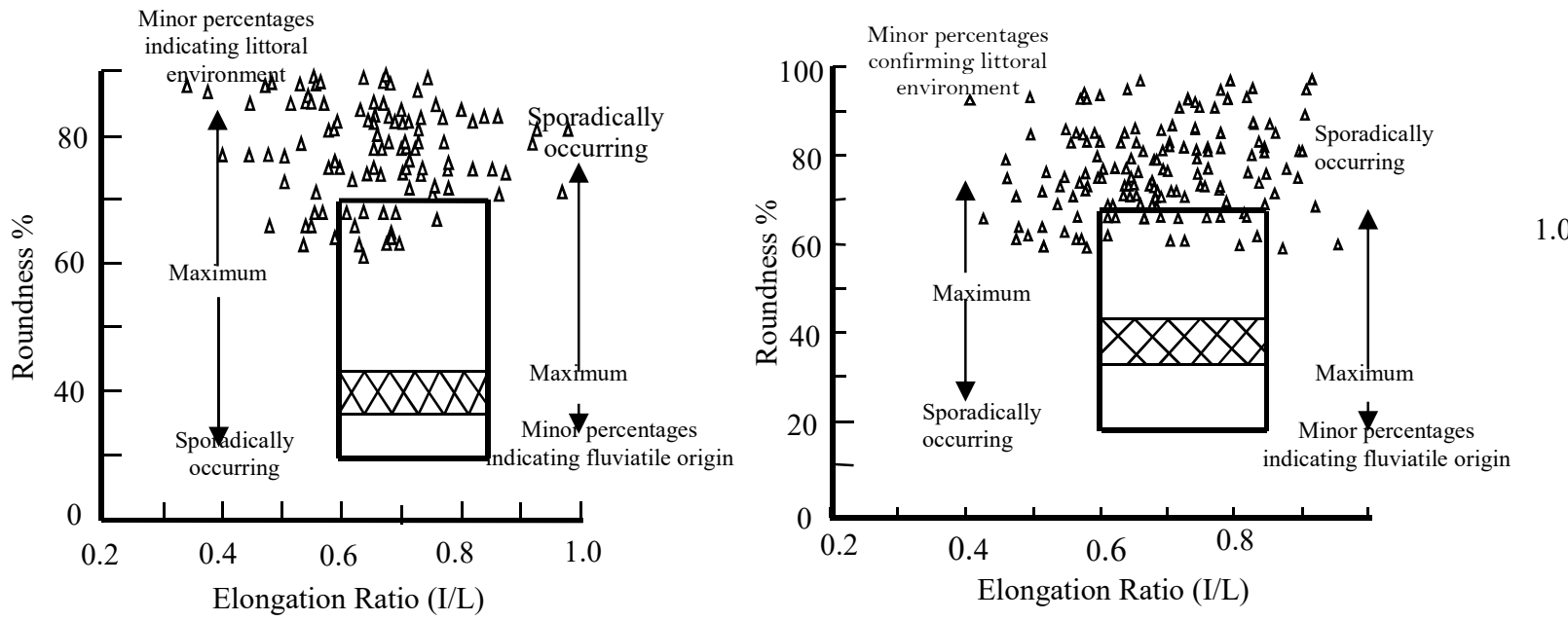

Fig. 6: Plot of Roundness against elongation Ratio using environmental determination chart of Sames (1966) for location 1 and 2 
Table 8a: Seive Analysis Result (Graphic method) for the Ogwashi-Asaba Formation

\begin{tabular}{|c|c|c|c|c|c|c|}
\hline $\begin{array}{l}\text { Sample } \\
\text { no }\end{array}$ & Median & Mean $\left(M_{z}\right)$ & $\begin{array}{l}\text { Standard } \\
\text { deviation } \sigma_{2}\end{array}$ & $\begin{array}{l}\text { Kurtosis } \\
\text { (KG) }\end{array}$ & $\begin{array}{l}\text { Skewness } \\
\text { (Ski) }\end{array}$ & $\begin{array}{l}\text { Interpretation / } \\
\text { Remarks }\end{array}$ \\
\hline A1 & 1.5 & 1.4 & 0.67 & 0.93 & -0.18 & $\mathrm{~m}, \mathrm{ps}, \mathrm{ns}, \mathrm{M}$ \\
\hline $\mathrm{A} 2$ & 1.6 & 1.08 & 1.17 & 1.05 & -0.18 & m,ps,ns,M. \\
\hline A3 & 1.5 & 1.5 & 1.48 & 0.81 & 0.67 & $\mathrm{~m}, \mathrm{ps}, \mathrm{vps}, \mathrm{M}$ \\
\hline A4 & 0.8 & -0.8 & 0.89 & 1.29 & -0.26 & $\mathrm{c}, \mathrm{mws}, \mathrm{ns}, \mathrm{L}$ \\
\hline A5 & -1.7 & -0.3 & 2.29 & 0.82 & 0.75 & c, vps, vps, P \\
\hline A6 & 1.2 & 3 & 1.2 & 1 & -0.28 & $\mathrm{f}, \mathrm{ps}, \mathrm{ns}, \mathrm{M}$ \\
\hline A7 & 1.6 & 1.6 & 0.95 & 1.14 & -0.48 & $\mathrm{~m}, \mathrm{mws}, \mathrm{vps}, \mathrm{L}$ \\
\hline Average & & 1.10 & 1.2 & 1.0 & 0.04 & $\mathrm{~m}, \mathrm{ps}, \mathrm{vps}, \mathrm{M}$ \\
\hline
\end{tabular}

Table 8b: Sieve analysis Result (Moment measures) for the Ogwashi-Asaba Formation

\begin{tabular}{|c|c|c|c|c|c|}
\hline Sample no & $\begin{array}{c}\text { Mean Grain } \\
\text { size, Ist } \\
\text { moment }\end{array}$ & $\begin{array}{c}\text { Standard } \\
\text { Deviation of } \\
\text { sorting, 2 } \\
\text { moment }\end{array}$ & $\begin{array}{c}\text { Skewness 3 } \\
\text { moment }\end{array}$ & $\begin{array}{c}\text { Mean cubed } \\
\text { Deviation }\end{array}$ & $\begin{array}{c}\text { Interpretation } \\
\text { /Remarks }\end{array}$ \\
\hline A1 & 0.56 & 0.55 & 0.65 & 0.39 & $\mathrm{c}, \mathrm{mws}, \mathrm{vfs}$ \\
\hline A2 & 0.52 & 0.39 & 0.34 & 0.10 & $\mathrm{c}, \mathrm{ws}, \mathrm{vfs}$ \\
\hline A3 & 0.72 & 0.95 & 0.96 & 1.71 & $\mathrm{c}, \mathrm{ms}, \mathrm{vfs}$ \\
\hline A4 & 1.99 & 1.64 & 0.04 & 0.22 & $\mathrm{vc}, \mathrm{ps}, \mathrm{ns}$ \\
\hline A5 & 0.83 & 0.89 & 0.61 & 0.99 & $\mathrm{c}, \mathrm{ms}, \mathrm{vfs}$ \\
\hline A6 & 1.16 & 1.05 & 0.40 & 0.88 & $\mathrm{vc}, \mathrm{ps}, \mathrm{vfs}$ \\
\hline A7 & 0.29 & 0.44 & 0.54 & 0.21 & $\mathrm{c}, \mathrm{mws}, \mathrm{vfs}$ \\
\hline A8 & 0.65 & 0.72 & 0.56 & 0.58 & \\
\hline Average & 0.84 & 0.83 & 0.51 & 0.64 & \\
\hline
\end{tabular}

\subsection{Discussion of Results}

\subsection{Pebble Form Indices}

The mean elongation ratio for pebbles of Ogwashi-Asaba Formation $(0.661 \pm 0.21-0.686 \pm 0.118)$ from Ubakala lies within the $0.65-0.75$ range of Lutig's torrent type flowing waters or brooks and rivulets. The mean flatness ratio computed for the pebbles $(0.52 \pm 0.34-0.50 \pm 0.12)$ falls beyond the fluviatile range of $0.25-0.35$ and slightly above the marine range of $0.40-0.50$ (Lutig.1962). Certain shape classes of pebbles are diagnostic of depositional environments (Dobkins and Folk, 1970). The dominant pebble forms common in beaches include bladed, very bladed, platy, and very platy whereas elongate, compact elongate, compact, and compact bladed are indicative of fluviatile pebbles. The pebble form common in the studied area include elongate (29\%), compact elongate (22\%), bladed (21\%) and compact bladed (14\%), (Table 6) which are indicative of the dominance of fluvial processes over beach action in the area.

The maximum projection sphericity index (M.P.S.I) calculated for the Ogwashi-Asaba Formation pebbles at Ubakala $(0.71 \pm 0.10-0.73 \pm 0.22)$ lies above $0.65 / 0.66$ lower index limits that separates beach and fluvial pebbles. It has been established that pebbles with lower sphericity values are characterized by beach pebbles while those with higher sphericity values are suggestive of a fluvial environment (Dobkins and Folk, 1970). The sphericity values of the Ubakala pebbles are thus indicative of a fluvial setting.

The oblate-prolate index for pebbles of Ogwashi-Asaba Formation from Ubakala $(2.60 \pm 4.40-3.53 \pm 4.47)$ lies above the -1.5 lower index limit established by Dobkins and Folk (1970) that separates beach and fluvial pebbles. The oblate-prolate index values are suggestive of a fluvial depositional environment.

The mean values of the various form indices (Tables 5 and 8) for the two sets of pebble samples lie within the limits suggested for pebbles formed in a fluvial setting. The bivariate plots coefficient of flatness versus sphericity (Figs. 4 a-b), and sphericity versus oblate-prolate index (Figs. 4a-b) indicate that majority of the pebbles lie within the fluvial field. The plot of roundness versus elongation ratio suggests that $100 \%$ of the pebbles are in the littoral field (Fig. 5a-b). Plots made on the sphericity form diagram of Sneed and Folk (1958) (Fig.7) for the $3.0,-3.5,-4.0,-4.5,-5.0,-5.5$ phi size classes for the two locations studied confirm the finding that larger pebbles are generally more bladed than smaller ones. In a nutshell, the study of form indices of pebbles from OgwashiAsaba Formation has indicated the fluvial origin of these pebbles. The sphericity form plots also suggest a decrease in sphericity as size increases. 


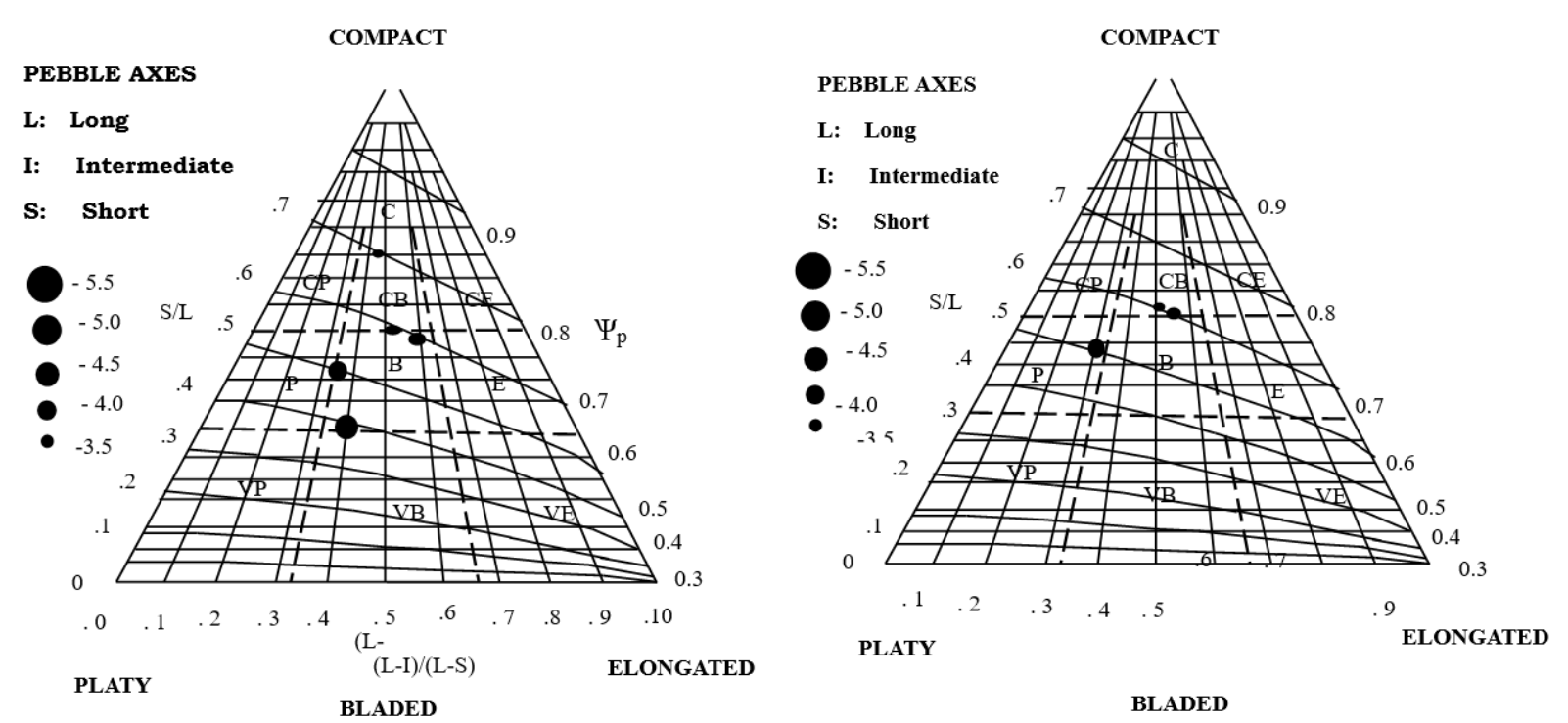

Fig 7: Sphericity-form diagram of Sneed and Folk (1958), Sphericity-form plots of mean indices of the -3.5, $4.0,-4.5,-5.0,-5.5$ phi size classes for Location 1 and Locaton 2.
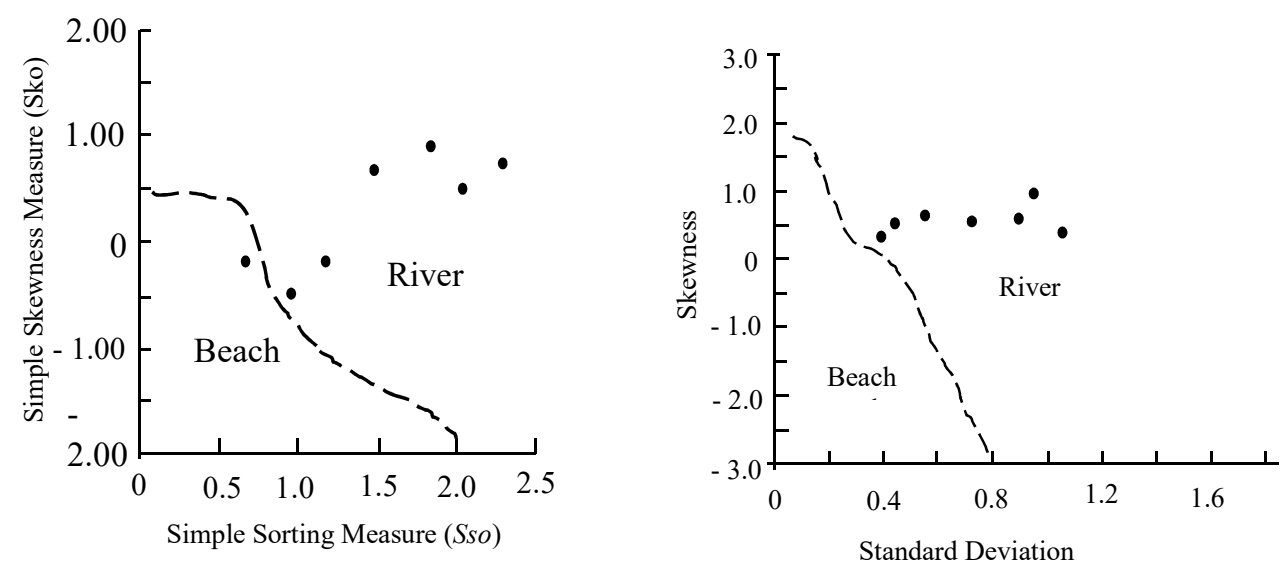

FIG: 8a Bivariate plot of Simple Skewness Measure (Sko) against Simple sorting measure (Sso) for Ogwashi- Asaba Formation and (b) Bivariate Plot of $3^{\text {rd }}$ moment (Skewness) against $2^{\text {nd }}$ moment standard deviation

\subsection{Textural Parameters}

Graphical plots of simple skewness measures versus simple standard deviation (Fig. 8a) and $3^{\text {rd }}$ moment skewness versus $2^{\text {nd }}$ moment standard deviation (Fig. 8b) for sandstones of the Ogwashi-Asaba Formation suggest a fluvial paleodepositional environment for the sandstones. The sieve analysis results in Table 7a suggests that the sandstones from the Ogwashi-Asaba Formation have grain sizes ranging from- 0.8 to 1.6 with an average of 1.10 (medium sand). The result of standard deviation ranges from 0.67 to 2.29 and suggests that the sands are well to poorly sorted

\subsection{Conclusison}

Odumodu and Isreal (2014) using pebble form indices inferred a fluvial depositional environment for the OgwashiAsaba Formation in Nnewi area in Anambra State. Results of their study gave the mean sphericity values to range from 0.605 to 0.834 , coefficient of flatness as 65.60 to 71.75 and oblate-prolate index as ranging from -1.869 to -0.877 . Results from the present study have yielded sphericity values that vary from 0.71 to 0.73 , coefficient of flatness values from 49.78 to 52.02 and oblate-prolate index values from 2.60 to 3.53 . All these values also fall within the range required for fluvial pebbles. The entire cross plots of the bivariate parameters are also indicative of a fluvial environment of deposition. A long distance of transport is inferred from the roundness index. The lithofacies also supports a braided fluvial channel, swamps and marshland as the depositional environments. 


\section{References}

Avbovbo, A.A. 1978. Tertiary Lithostratigraphy of the Niger Delta. American Association of Petroleum Geologists Bulletin, 62, pp. $295-300$.

Dobkins, J.E. and Folk, R.L. 1970. Shape development of Tahiti- Nui: Journal of Sedimentary Petrology, 40, pp. $1167-1203$

Du Preez JW (1946). A further investigation on the lignites of Onitsha Province. Annals of Reproductive Geological Society of Nigeria $25-26$.

Els BG (1988). Pebble Morphology of an ancient conglomerate: The Middelvlei Gold Placer, Witwatersrand, South Africa. Journal of Sedimentary Petrology 58(5) 894 - 90

Ephraim, B.E., Amaechina, C., and Odumodu, C.F.R. (2015) Pebble morphometric investigations on pebbles belonging to the Benin Formation at Nsie and environs, Southeastern Nigeria. Advances in Applied Science Research, 6 (6), 47-54.

Folk, R.L. 1974. Petrology of sedimentary rocks. Hemphil Publishing Company, Austin Texas,182p.

Friedman, G.M. 1979. Differences in size distributions of populations of particles among sands of various origins. Sedimentology, 26, pp $3-32$.

Krumbein, W.C., 1941. Measurements and geological significance of shape and roundness of sedimentary particles. Journal of Sedimentary Petrology, 11, pp. $64-72$.

Lutig G (1962). The shape of pebbles in the continental, fluviatile and marine facies. International Association of Scientific Hydrology Publication 59253 - 258.

Nwajide CS and Hoque M (1982). Pebble Morphometry as an aid in environmental diagnosis: an example from the Middle Benue Trough, Nigerian Journal of Mining and Geology 19 (1) $114-120$.

Odumodu, C.F. (2014). Pebble form indices as signature for the depositional environment of the Benin Formation along Atamiri River, Uli, southeastern Nigeria. International Journal of Scientific and Technological Research. 3 (1), 23 - 32.

Odumodu CFR and Ephraim BE (2007a). Paleoenvironmental analysis of the Nsukka Formation, using pebble morphology. Natural and Applied Sciences Journal 8 (1) 73 - 84.

Odumodu CFR and Ephraim BE (2007b). Pebble Morphometry as an indicator of the depositional environment of the Ajali Sandstone. Natural and Applied Sciences Journal 8 (2) 132 - 143.

Odumodu, C.F.R. and Nfor, B.N. (2013). Facies and granulometric analysis as proxies for the paleodepositional environment of the Imo Formation, southeastern Nigeria. Journal of environment and earth science 3(14) 52 -70 .

Odumodu. C.F.R. and Isreal, H.O. (2014). Pebble form indices as paleoenvironmental reconstruction tools for the Ogwashi-Asaba Formation, southeastern Nigeria. International Journal of Geology, Earth and Environmental Sciences, 4 (3), 149-159.

Odumodu, P.N. and Odumodu, C.F. (2012) Pebble morphology of the Conglomeritic arkosic sandstone unit of the Ogoja Sandstone, Ogoja, southeastern Nigeria. Journal of Basic Physical Research. 3, 40 - 50.

Okezie CN and Onuogu SA (1985). The lignite's of Southeastern Nigeria. Geological Survey of Nigeria Occupation Paper 1028.

Sames CW (1966). Morphometric data of some recent pebble associations and their application to ancient deposits. Journal of Sedimentary Petrology $36126-142$.

Short, K.C. and Stauble, E.A. (1967). Outline Geology of the Niger Delta. American Association of the Petroleum Geologists Bulletin. 51, pp. $761-781$.

Simpson (1954). The Nigerian coalfield; the geology of parts of Onitsha, Owerri, and Benue provinces. Geological Survey of Nigeria Bulletin $241-85$.

Sneed ED and Folk RE (1958). Pebbles in the lower Colorado River, Texas: a study of particle morphogenesis. Journal of Geology 66114 - 150.

Tucker, M.E. 1981. Sedimentary Petrology; An Introduction. John Wiley and Sons Inc., New York, p 25.

Umeji, OP (2003). Palynological data from the road section at Ogbunike toll gate, Onitsha, Southeastern Nigerian Journal of Mining and Geology 39(2) $95-102$

Wilson RC (1925). The Geology of the Eastern railway. Geological Survey of Nigeria Bulletin 1 - 95.

Wilson RC and Bain ADN (1928). The Nigerian coalfield (section II) parts of Onitsha and Owerri provinces. Geological Survey of Nigeria Bulletin $121-5$. 
ISSN 2224-3186 (Paper) ISSN 2225-0921 (Online) DOI: 10.7176/JNSR

Vol.9, No.6, 2019

Table 9a: Results of pebble morphometric study of Ogwashi-Asaba Formation at Location 1

\begin{tabular}{|c|c|c|c|c|c|c|c|c|c|c|c|}
\hline & $\mathbf{L}$ & I & $\mathbf{S}$ & $\mathrm{S} / \mathrm{L}$ & $\mathrm{S} / \mathrm{L} * 100$ & $\mathbf{I} / \mathbf{L}$ & L-I/L-S & SPHERICITY & $\begin{array}{l}\text { OP } \\
\text { INDEX }\end{array}$ & $\begin{array}{l}\text { ROUN } \\
\text { DNESS }\end{array}$ & \\
\hline 1 & 52.7 & 25.2 & 20 & 0.38 & 37.951 & 0.478 & 0.841 & 0.67 & 8.985 & 0.66 & $E$ \\
\hline 2 & 41.8 & 25.3 & 14.1 & 0.337 & 33.732 & 0.605 & 0.596 & 0.573 & 2.836 & 0.68 & $\mathrm{~B}$ \\
\hline 3 & 48.4 & 26.1 & 22.3 & 0.461 & 46.074 & 0.539 & 0.854 & 0.733 & 7.692 & 0.66 & $E$ \\
\hline 4 & 48.3 & 30.8 & 26.1 & 0.54 & 54.037 & 0.638 & 0.788 & 0.771 & 5.335 & 0.68 & $\mathrm{CE}$ \\
\hline 5 & 46.4 & 23.4 & 18.1 & 0.39 & 39.009 & 0.504 & 0.813 & 0.671 & 8.017 & 0.73 & $E$ \\
\hline 6 & 71.2 & 52.6 & 22.4 & 0.315 & 31.461 & 0.739 & 0.381 & 0.512 & -3.78 & 0.93 & $\mathrm{~B}$ \\
\hline 7 & 59.2 & 46 & 31.4 & 0.53 & 53.041 & 0.777 & 0.475 & 0.713 & -0.47 & 0.72 & $\mathrm{CB}$ \\
\hline 8 & 43.2 & 19.3 & 16.9 & 0.391 & 39.12 & 0.447 & 0.909 & 0.7 & 10.45 & 0.85 & $E$ \\
\hline 9 & 39.4 & 21 & 17.1 & 0.434 & 43.401 & 0.533 & 0.825 & 0.707 & 7.491 & 0.79 & $E$ \\
\hline 10 & 43.2 & 20.6 & 16.1 & 0.373 & 37.269 & 0.477 & 0.834 & 0.663 & 8.961 & 0.77 & $E$ \\
\hline 11 & 33.4 & 23.8 & 11.1 & 0.332 & 33.234 & 0.713 & 0.43 & 0.537 & -2.09 & 0.76 & $\mathrm{~B}$ \\
\hline 12 & 43.5 & 24.7 & 19.7 & 0.453 & 45.287 & 0.568 & 0.79 & 0.712 & 6.402 & 0.68 & $E$ \\
\hline 13 & 29.3 & 19.5 & 14.2 & 0.485 & 48.464 & 0.666 & 0.649 & 0.707 & 3.075 & 0.78 & $\mathrm{~B}$ \\
\hline 14 & 49.3 & 43.1 & 18.5 & 0.375 & 37.525 & 0.874 & 0.201 & 0.544 & -7.96 & 0.74 & $E$ \\
\hline 15 & 65.3 & 42.2 & 29.6 & 0.453 & 45.329 & 0.646 & 0.647 & 0.683 & 3.244 & 0.82 & B \\
\hline 16 & 25.3 & 18.5 & 14.3 & 0.565 & 56.522 & 0.731 & 0.618 & 0.759 & 2.091 & 0.83 & $\mathrm{CE}$ \\
\hline 17 & 34.9 & 26.8 & 20.5 & 0.587 & 58.739 & 0.768 & 0.563 & 0.766 & 1.064 & 0.98 & $\mathrm{CB}$ \\
\hline 18 & 37.7 & 29 & 19.2 & 0.509 & 50.928 & 0.769 & 0.47 & 0.696 & -0.58 & 0.79 & $\mathrm{CB}$ \\
\hline 19 & 31 & 16.6 & 14.8 & 0.477 & 47.742 & 0.535 & 0.889 & 0.752 & 8.146 & 0.85 & $\mathrm{E}$ \\
\hline 20 & 40.9 & 26.8 & 19.6 & 0.479 & 47.922 & 0.655 & 0.662 & 0.705 & 3.38 & 0.75 & $E$ \\
\hline 21 & 32.5 & 18.5 & 15.1 & 0.465 & 46.462 & 0.569 & 0.805 & 0.724 & 6.556 & 0.85 & $E$ \\
\hline 22 & 32.6 & 18.1 & 16.9 & 0.518 & 51.84 & 0.555 & 0.924 & 0.785 & 8.171 & 0.88 & $\mathrm{CE}$ \\
\hline 23 & 32.3 & 21.1 & 14.6 & 0.452 & 45.201 & 0.653 & 0.633 & 0.679 & 2.937 & 0.83 & B \\
\hline 24 & 47.5 & 42.2 & 19.8 & 0.417 & 41.684 & 0.888 & 0.191 & 0.58 & -7.4 & 0.99 & $E$ \\
\hline 25 & 46.6 & 26.9 & 21.1 & 0.453 & 45.279 & 0.577 & 0.773 & 0.708 & 6.019 & 0.81 & $E$ \\
\hline 25 & 42.9 & 36.9 & 20 & 0.466 & 46.62 & 0.86 & 0.262 & 0.632 & -5.1 & 0.83 & $\mathrm{P}$ \\
\hline 27 & 30 & 23.3 & 20.3 & 0.677 & 67.667 & 0.777 & 0.691 & 0.839 & 2.819 & 0.76 & $\mathrm{CE}$ \\
\hline 28 & 32.4 & 19.1 & 14.9 & 0.46 & 45.988 & 0.59 & 0.76 & 0.711 & 5.654 & 0.76 & $E$ \\
\hline 29 & 27.8 & 18.9 & 12.1 & 0.435 & 43.525 & 0.68 & 0.567 & 0.653 & 1.537 & 0.88 & B \\
\hline 30 & 32.1 & 24.3 & 17.9 & 0.558 & 55.763 & 0.757 & 0.549 & 0.743 & 0.884 & 0.67 & $\mathrm{CB}$ \\
\hline 31 & 37.7 & 24.5 & 19.3 & 0.512 & 51.194 & 0.65 & 0.717 & 0.739 & 4.246 & 0.74 & $\mathrm{CE}$ \\
\hline 32 & 47.2 & 30.7 & 24.4 & 0.517 & 51.695 & 0.65 & 0.724 & 0.743 & 4.327 & 0.85 & $\mathrm{CE}$ \\
\hline 33 & 48.4 & 25.1 & 17.1 & 0.353 & 35.331 & 0.519 & 0.744 & 0.622 & 6.918 & 0.94 & $E$ \\
\hline 34 & 37.5 & 26.5 & 23.8 & 0.635 & 63.467 & 0.707 & 0.803 & 0.829 & 4.773 & 0.75 & $\mathrm{CE}$ \\
\hline 35 & 33 & 22.4 & 15.3 & 0.464 & 46.364 & 0.679 & 0.599 & 0.682 & 2.132 & 0.83 & B \\
\hline 36 & 80.1 & 44.5 & 23.4 & 0.292 & 29.213 & 0.556 & 0.628 & 0.536 & 4.377 & 0.71 & VB \\
\hline 37 & 25.5 & 14.4 & 13.2 & 0.518 & 51.765 & 0.565 & 0.902 & 0.78 & 7.774 & 0.85 & $\mathrm{CE}$ \\
\hline 38 & 23.4 & 19.6 & 12.8 & 0.547 & 54.701 & 0.838 & 0.358 & 0.71 & -2.59 & 0.83 & $\mathrm{CB}$ \\
\hline 39 & 18.1 & 17.5 & 15.1 & 0.834 & 83.425 & 0.967 & 0.2 & 0.896 & -3.6 & 0.71 & $\mathrm{C}$ \\
\hline 40 & 24.9 & 16.2 & 12.6 & 0.506 & 50.602 & 0.651 & 0.707 & 0.733 & 4.097 & 0.82 & $\mathrm{CE}$ \\
\hline 41 & 39.4 & 21.5 & 14.3 & 0.363 & 36.294 & 0.546 & 0.713 & 0.623 & 5.873 & 0.86 & $E$ \\
\hline 42 & 36.3 & 24.3 & 16.4 & 0.452 & 45.179 & 0.669 & 0.603 & 0.673 & 2.28 & 0.85 & B \\
\hline 43 & 31.2 & 20 & 18.7 & 0.599 & 59.936 & 0.641 & 0.896 & 0.824 & 6.607 & 0.82 & $\mathrm{CE}$ \\
\hline 44 & 26.4 & 14.7 & 12.2 & 0.462 & 46.212 & 0.557 & 0.824 & 0.727 & 7.01 & 0.68 & $E$ \\
\hline 45 & 16.7 & 16.3 & 15.7 & 0.94 & 94.012 & 0.976 & 0.4 & 0.967 & -1.06 & 0.81 & $\mathrm{C}$ \\
\hline 46 & 31.5 & 20.7 & 14.2 & 0.451 & 45.079 & 0.657 & 0.624 & 0.676 & 2.757 & 0.75 & $\mathrm{~B}$ \\
\hline 47 & 26.8 & 18.9 & 14.9 & 0.556 & 55.597 & 0.705 & 0.664 & 0.76 & 2.947 & 0.92 & $\mathrm{CE}$ \\
\hline 48 & 21.9 & 15.9 & 14.8 & 0.676 & 67.58 & 0.726 & 0.845 & 0.857 & 5.106 & 0.87 & $\mathrm{CE}$ \\
\hline 49 & 57.9 & 31.8 & 22.4 & 0.387 & 38.687 & 0.549 & 0.735 & 0.648 & 6.08 & 0.85 & B \\
\hline 50 & 33.1 & 19.7 & 17.3 & 0.523 & 52.266 & 0.595 & 0.848 & 0.771 & 6.66 & 0.75 & $\mathrm{CE}$ \\
\hline 51 & 34.2 & 29.1 & 18.8 & 0.55 & 54.971 & 0.851 & 0.331 & 0.708 & -3.07 & 0.75 & $\mathrm{CP}$ \\
\hline 52 & 43.2 & 18.9 & 15.5 & 0.359 & 35.88 & 0.438 & 0.877 & 0.665 & 10.51 & 0.94 & $E$ \\
\hline 53 & 30.8 & 18.1 & 12.5 & 0.406 & 40.584 & 0.588 & 0.694 & 0.654 & 4.78 & 0.81 & $E$ \\
\hline 54 & 28.7 & 15.2 & 13.6 & 0.474 & 47.387 & 0.53 & 0.894 & 0.751 & 8.315 & 0.88 & $E$ \\
\hline 55 & 30.9 & 18.2 & 11.3 & 0.366 & 36.57 & 0.589 & 0.648 & 0.61 & 4.046 & 0.82 & B \\
\hline 56 & 31.3 & 22 & 19.5 & 0.623 & 62.3 & 0.703 & 0.788 & 0.82 & 4.625 & 0.82 & $\mathrm{CE}$ \\
\hline 57 & 26.1 & 16.1 & 15.9 & 0.609 & 60.92 & 0.617 & 0.98 & 0.844 & 7.886 & 0.73 & $\mathrm{CE}$ \\
\hline 58 & 18.6 & 15.2 & 13.5 & 0.726 & 72.581 & 0.817 & 0.667 & 0.864 & 2.296 & 0.82 & $\mathrm{C}$ \\
\hline 59 & 30.8 & 18.7 & 11.9 & 0.386 & 38.636 & 0.607 & 0.64 & 0.626 & 3.629 & 0.68 & $\mathrm{~B}$ \\
\hline 60 & 32.8 & 24.9 & 12.6 & 0.384 & 38.415 & 0.759 & 0.391 & 0.579 & -2.84 & 0.67 & B \\
\hline 61 & 23.9 & 20.4 & 18.9 & 0.791 & 79.079 & 0.854 & 0.7 & 0.901 & 2.529 & 0.93 & $\mathrm{C}$ \\
\hline 62 & 29.7 & 20 & 17.7 & 0.596 & 59.596 & 0.673 & 0.808 & 0.808 & 5.174 & 0.95 & $\mathrm{CE}$ \\
\hline 63 & 35.6 & 24.1 & 21.5 & 0.604 & 60.393 & 0.677 & 0.816 & 0.814 & 5.226 & 0.79 & $\mathrm{CE}$ \\
\hline 64 & 32.7 & 20.6 & 15.9 & 0.486 & 48.624 & 0.63 & 0.72 & 0.721 & 4.529 & 0.84 & $E$ \\
\hline 65 & 28.5 & 16.5 & 14.6 & 0.512 & 51.228 & 0.579 & 0.863 & 0.768 & 7.092 & 0.75 & $\mathrm{CE}$ \\
\hline 66 & 21.9 & 17.9 & 17.3 & 0.79 & 78.995 & 0.817 & 0.87 & 0.914 & 4.678 & 0.75 & $\mathrm{C}$ \\
\hline 67 & 26.3 & 16.9 & 15.4 & 0.586 & 58.555 & 0.643 & 0.862 & 0.811 & 6.189 & 0.74 & $\mathrm{CE}$ \\
\hline
\end{tabular}




\begin{tabular}{|c|c|c|c|c|c|c|c|c|c|c|c|}
\hline & $\mathbf{L}$ & I & $\mathbf{S}$ & $\mathrm{S} / \mathrm{L}$ & $\mathrm{S} / \mathrm{L} * 100$ & $\mathbf{I} / \mathbf{L}$ & L-I/L-S & SPHERICITY & $\begin{array}{l}\text { OP } \\
\text { INDEX }\end{array}$ & $\begin{array}{l}\text { ROUN } \\
\text { DNESS }\end{array}$ & \\
\hline 68 & 27.4 & 18.4 & 11.7 & 0.427 & 42.701 & 0.672 & 0.573 & 0.648 & 1.715 & 0.88 & $\mathrm{~B}$ \\
\hline 69 & 21.4 & 16.5 & 15.4 & 0.72 & 71.963 & 0.771 & 0.817 & 0.876 & 4.4 & 0.93 & $\mathrm{C}$ \\
\hline 70 & 27.2 & 16.8 & 11.8 & 0.434 & 43.382 & 0.618 & 0.675 & 0.673 & 4.041 & 0.95 & $E$ \\
\hline 71 & 20.1 & 13.8 & 11.4 & 0.567 & 56.716 & 0.687 & 0.724 & 0.777 & 3.952 & 0.82 & $\mathrm{CE}$ \\
\hline 72 & 15.9 & 14.7 & 11.1 & 0.698 & 69.811 & 0.925 & 0.25 & 0.808 & -3.58 & 0.81 & $\mathrm{C}$ \\
\hline 73 & 26.4 & 17.5 & 12.9 & 0.489 & 48.864 & 0.663 & 0.659 & 0.712 & 3.259 & 0.74 & $\mathrm{~B}$ \\
\hline 74 & 30.5 & 21.1 & 15.4 & 0.505 & 50.492 & 0.692 & 0.623 & 0.717 & 2.426 & 0.93 & $\mathrm{CB}$ \\
\hline 75 & 24.2 & 16.9 & 12.7 & 0.525 & 52.479 & 0.698 & 0.635 & 0.733 & 2.568 & 0.84 & $\mathrm{CB}$ \\
\hline 76 & 22.9 & 17.6 & 12.9 & 0.563 & 56.332 & 0.769 & 0.53 & 0.745 & 0.533 & 0.83 & $\mathrm{CB}$ \\
\hline 77 & 24.1 & 15.3 & 14.4 & 0.598 & 59.751 & 0.635 & 0.907 & 0.825 & 6.815 & 0.61 & $\mathrm{CE}$ \\
\hline 78 & 24.3 & 13.3 & 9.3 & 0.383 & 38.272 & 0.547 & 0.733 & 0.644 & 6.097 & 0.66 & $E$ \\
\hline 79 & 22.9 & 15.3 & 11.3 & 0.493 & 49.345 & 0.668 & 0.655 & 0.714 & 3.145 & 0.68 & B \\
\hline 80 & 27.6 & 20.5 & 12 & 0.435 & 43.478 & 0.743 & 0.455 & 0.634 & -1.03 & 0.89 & B \\
\hline 81 & 27.4 & 22.7 & 9.9 & 0.361 & 36.131 & 0.828 & 0.269 & 0.54 & -6.41 & 0.93 & $\mathrm{P}$ \\
\hline 82 & 25.9 & 20.9 & 9.9 & 0.382 & 38.224 & 0.807 & 0.313 & 0.566 & -4.91 & 0.99 & $\mathrm{P}$ \\
\hline 83 & 31.2 & 23.4 & 11.5 & 0.369 & 36.859 & 0.75 & 0.396 & 0.566 & -2.82 & 0.71 & B \\
\hline 84 & 23.1 & 18.3 & 10.5 & 0.455 & 45.455 & 0.792 & 0.381 & 0.639 & -2.62 & 0.98 & $\mathrm{~B}$ \\
\hline 85 & 20.5 & 14.9 & 12.5 & 0.61 & 60.976 & 0.727 & 0.7 & 0.8 & 3.28 & 0.81 & $\mathrm{CE}$ \\
\hline 86 & 23.1 & 17.9 & 11.4 & 0.494 & 49.351 & 0.775 & 0.444 & 0.68 & -1.13 & 0.75 & $\mathrm{~B}$ \\
\hline 87 & 21.1 & 17.2 & 11.4 & 0.54 & 54.028 & 0.815 & 0.402 & 0.71 & -1.81 & 0.97 & $\mathrm{CB}$ \\
\hline 88 & 44.1 & 15.5 & 14.5 & 0.329 & 32.88 & 0.351 & 0.966 & 0.675 & 14.18 & 0.93 & $E$ \\
\hline 89 & 24.1 & 19.4 & 15.1 & 0.627 & 62.656 & 0.805 & 0.522 & 0.787 & 0.355 & 0.93 & $\mathrm{CB}$ \\
\hline 90 & 28.1 & 21.1 & 11.2 & 0.399 & 39.858 & 0.751 & 0.414 & 0.596 & -2.15 & 0.98 & $\mathrm{~B}$ \\
\hline 91 & 26 & 22.4 & 14.9 & 0.573 & 57.308 & 0.862 & 0.324 & 0.725 & -3.07 & 0.71 & $\mathrm{CB}$ \\
\hline 92 & 18.5 & 16.9 & 8.9 & 0.481 & 48.108 & 0.914 & 0.167 & 0.633 & -6.93 & 0.97 & $\mathrm{CP}$ \\
\hline 93 & 24.2 & 18.3 & 15.3 & 0.632 & 63.223 & 0.756 & 0.663 & 0.809 & 2.577 & 0.85 & $\mathrm{CE}$ \\
\hline 94 & 19.5 & 17.9 & 9.9 & 0.508 & 50.769 & 0.918 & 0.167 & 0.655 & -6.57 & 0.79 & $\mathrm{CP}$ \\
\hline 95 & 25.4 & 19.2 & 15.7 & 0.618 & 61.811 & 0.756 & 0.639 & 0.797 & 2.252 & 0.72 & $\mathrm{CB}$ \\
\hline 96 & 39.6 & 31.6 & 18.7 & 0.472 & 47.222 & 0.798 & 0.383 & 0.654 & -2.48 & 0.84 & $\mathrm{~B}$ \\
\hline 97 & 20.9 & 13.3 & 13.3 & 0.636 & 63.636 & 0.636 & 1 & 0.86 & 7.857 & 0.89 & $\mathrm{CE}$ \\
\hline 98 & 44.3 & 19.1 & 16 & 0.361 & 36.117 & 0.431 & 0.89 & 0.671 & 10.81 & 0.94 & $E$ \\
\hline 99 & 34.1 & 24.1 & 21.8 & 0.639 & 63.93 & 0.707 & 0.813 & 0.833 & 4.896 & 0.79 & $\mathrm{CE}$ \\
\hline 100 & 48.4 & 23.3 & 20.9 & 0.432 & 43.182 & 0.481 & 0.913 & 0.729 & 9.558 & 0.88 & $E$ \\
\hline 101 & 39.5 & 25.5 & 25 & 0.633 & 63.291 & 0.646 & 0.966 & 0.853 & 7.355 & 0.96 & $\mathrm{CB}$ \\
\hline 102 & 46.8 & 25.7 & 20.8 & 0.444 & 44.444 & 0.549 & 0.812 & 0.711 & 7.01 & 0.89 & $E$ \\
\hline 103 & 37.5 & 22.4 & 16.5 & 0.44 & 44 & 0.597 & 0.719 & 0.687 & 4.978 & 0.96 & $E$ \\
\hline 104 & 30.7 & 15.8 & 15 & 0.489 & 48.86 & 0.515 & 0.949 & 0.774 & 9.19 & 0.85 & $E$ \\
\hline 105 & 31.5 & 23.1 & 14.5 & 0.46 & 46.032 & 0.733 & 0.494 & 0.661 & -0.13 & 0.75 & B \\
\hline 106 & 38.7 & 21 & 18 & 0.465 & 46.512 & 0.543 & 0.855 & 0.736 & 7.634 & 0.94 & $E$ \\
\hline 107 & 38.4 & 25.8 & 16.5 & 0.43 & 42.969 & 0.672 & 0.575 & 0.65 & 1.753 & 0.89 & B \\
\hline 108 & 37.4 & 14 & 9 & 0.241 & 24.064 & 0.374 & 0.824 & 0.537 & 13.46 & 0.87 & $\mathrm{VE}$ \\
\hline 109 & 31.6 & 22.3 & 17.6 & 0.557 & 55.696 & 0.706 & 0.664 & 0.76 & 2.95 & 0.82 & $\mathrm{CE}$ \\
\hline 110 & 31.7 & 19.9 & 19.2 & 0.606 & 60.568 & 0.628 & 0.944 & 0.836 & 7.331 & 0.96 & $\mathrm{CE}$ \\
\hline 111 & 37.7 & 12.8 & 10.6 & 0.281 & 28.117 & 0.34 & 0.919 & 0.615 & 14.9 & 0.88 & $\mathrm{VE}$ \\
\hline 112 & 27.4 & 20 & 15.4 & 0.562 & 56.204 & 0.73 & 0.617 & 0.756 & 2.076 & 0.74 & $\mathrm{CB}$ \\
\hline 113 & 37.5 & 26.7 & 17.1 & 0.456 & 45.6 & 0.712 & 0.529 & 0.663 & 0.645 & 0.72 & $\mathrm{~B}$ \\
\hline 114 & 29 & 18 & 13 & 0.448 & 44.828 & 0.621 & 0.688 & 0.687 & 4.183 & 0.66 & $E$ \\
\hline 115 & 26.4 & 18 & 14.9 & 0.564 & 56.439 & 0.682 & 0.73 & 0.776 & 4.083 & 0.65 & $\mathrm{CE}$ \\
\hline 116 & 34.2 & 24 & 13.3 & 0.389 & 38.889 & 0.702 & 0.488 & 0.6 & -0.31 & 0.74 & $\mathrm{~B}$ \\
\hline 117 & 31.3 & 22.8 & 16.9 & 0.54 & 53.994 & 0.728 & 0.59 & 0.737 & 1.672 & 0.79 & $\mathrm{CB}$ \\
\hline 118 & 32.2 & 22.2 & 14 & 0.435 & 43.478 & 0.689 & 0.549 & 0.65 & 1.137 & 0.68 & $\mathrm{~B}$ \\
\hline 119 & 38.7 & 19.5 & 17.3 & 0.447 & 44.703 & 0.504 & 0.897 & 0.735 & 8.885 & 0.77 & $E$ \\
\hline 120 & 24.6 & 17.2 & 13.5 & 0.549 & 54.878 & 0.699 & 0.667 & 0.755 & 3.037 & 0.78 & $\mathrm{CP}$ \\
\hline 121 & 26.3 & 19 & 15.8 & 0.601 & 60.076 & 0.722 & 0.695 & 0.793 & 3.25 & 0.78 & $\mathrm{CE}$ \\
\hline 122 & 27.8 & 19 & 16 & 0.576 & 57.554 & 0.683 & 0.746 & 0.786 & 4.27 & 0.64 & $\mathrm{CE}$ \\
\hline 123 & 33.9 & 16 & 11.3 & 0.333 & 33.333 & 0.472 & 0.792 & 0.617 & 8.761 & 0.88 & $E$ \\
\hline 124 & 36 & 18.8 & 15.7 & 0.436 & 43.611 & 0.522 & 0.847 & 0.714 & 7.963 & 0.94 & $E$ \\
\hline 125 & 38.2 & 21.4 & 14 & 0.366 & 36.649 & 0.56 & 0.694 & 0.621 & 5.299 & 0.88 & $E$ \\
\hline 126 & 26.9 & 18.7 & 16 & 0.595 & 59.48 & 0.695 & 0.752 & 0.798 & 4.242 & 0.63 & $\mathrm{CE}$ \\
\hline 127 & 24.5 & 16 & 10 & 0.408 & 40.816 & 0.653 & 0.586 & 0.634 & 2.112 & 0.78 & B \\
\hline 128 & 31.5 & 12.6 & 11.5 & 0.365 & 36.508 & 0.4 & 0.945 & 0.693 & 12.19 & 0.77 & $E$ \\
\hline 129 & 24.9 & 20.2 & 12.4 & 0.498 & 49.799 & 0.811 & 0.376 & 0.674 & -2.49 & 0.99 & $E$ \\
\hline 130 & 26.1 & 22.1 & 17.5 & 0.67 & 67.05 & 0.847 & 0.465 & 0.81 & -0.52 & 0.91 & $\mathrm{C}$ \\
\hline 131 & 25.3 & 15.9 & 14.1 & 0.557 & 55.731 & 0.628 & 0.839 & 0.791 & 6.088 & 0.63 & $E$ \\
\hline 132 & 25.5 & 14.6 & 11.8 & 0.463 & 46.275 & 0.573 & 0.796 & 0.72 & 6.388 & 0.92 & $E$ \\
\hline 133 & 27.5 & 15 & 116 & 4.218 & 421.82 & 0.545 & -0.14 & 3.195 & -1.52 & 0.95 & \\
\hline 134 & 28.6 & 19.3 & 16.8 & 0.587 & 58.741 & 0.675 & 0.788 & 0.8 & 4.905 & 0.63 & $\mathrm{CE}$ \\
\hline 135 & 27.4 & 14.7 & 10.5 & 0.383 & 38.321 & 0.536 & 0.751 & 0.649 & 6.562 & 0.63 & $\mathrm{E}$ \\
\hline
\end{tabular}


Vol.9, No.6, 2019

\begin{tabular}{|l|l|l|l|l|l|l|l|l|l|l|l|}
\hline & $\mathbf{L}$ & $\mathbf{I}$ & $\mathbf{S}$ & $\mathbf{S / L}$ & $\mathbf{S / L} \mathbf{*} 100$ & $\mathbf{I} / \mathbf{L}$ & $\mathbf{L - I / L - S}$ & SPHERICITY & $\begin{array}{l}\text { OP } \\
\text { INDEX }\end{array}$ & $\begin{array}{l}\text { ROUN } \\
\text { DNESS }\end{array}$ & \\
\hline 136 & 24.1 & 17 & 10.3 & 0.427 & 42.739 & 0.705 & 0.514 & 0.637 & 0.339 & 0.78 & $\mathrm{~B}$ \\
\hline 137 & 32 & 14.5 & 11.5 & 0.359 & 35.938 & 0.453 & 0.854 & 0.658 & 9.841 & 0.95 & $\mathrm{E}$ \\
\hline 138 & 34 & 20 & 13.4 & 0.394 & 39.412 & 0.588 & 0.68 & 0.642 & 4.557 & 0.64 & $\mathrm{~B}$ \\
\hline 139 & 31.5 & 19.6 & 13.6 & 0.432 & 43.175 & 0.622 & 0.665 & 0.669 & 3.817 & 0.98 & $\mathrm{E}$ \\
\hline 140 & 30 & 13.3 & 11 & 0.367 & 36.667 & 0.443 & 0.879 & 0.672 & 10.33 & 0.77 & $\mathrm{E}$ \\
\hline Mean & 32.809 & 21.2 & 16.33 & 0.52 & 52.019 & 0.661 & 0.661 & 0.732 & 3.529 & 0.79792 & $\mathrm{CE}$ \\
\hline $\begin{array}{l}\text { Standard } \\
\text { Deviation }\end{array}$ & 10.357 & 6.73 & 9.404 & 0.335 & 33.502 & 0.127 & 0.21 & 0.227 & 4.466 & 0.08298 & \\
\hline
\end{tabular}

Table 9b: Results of pebble morphometric study of Ogwashi-Asaba Formation at Location 2

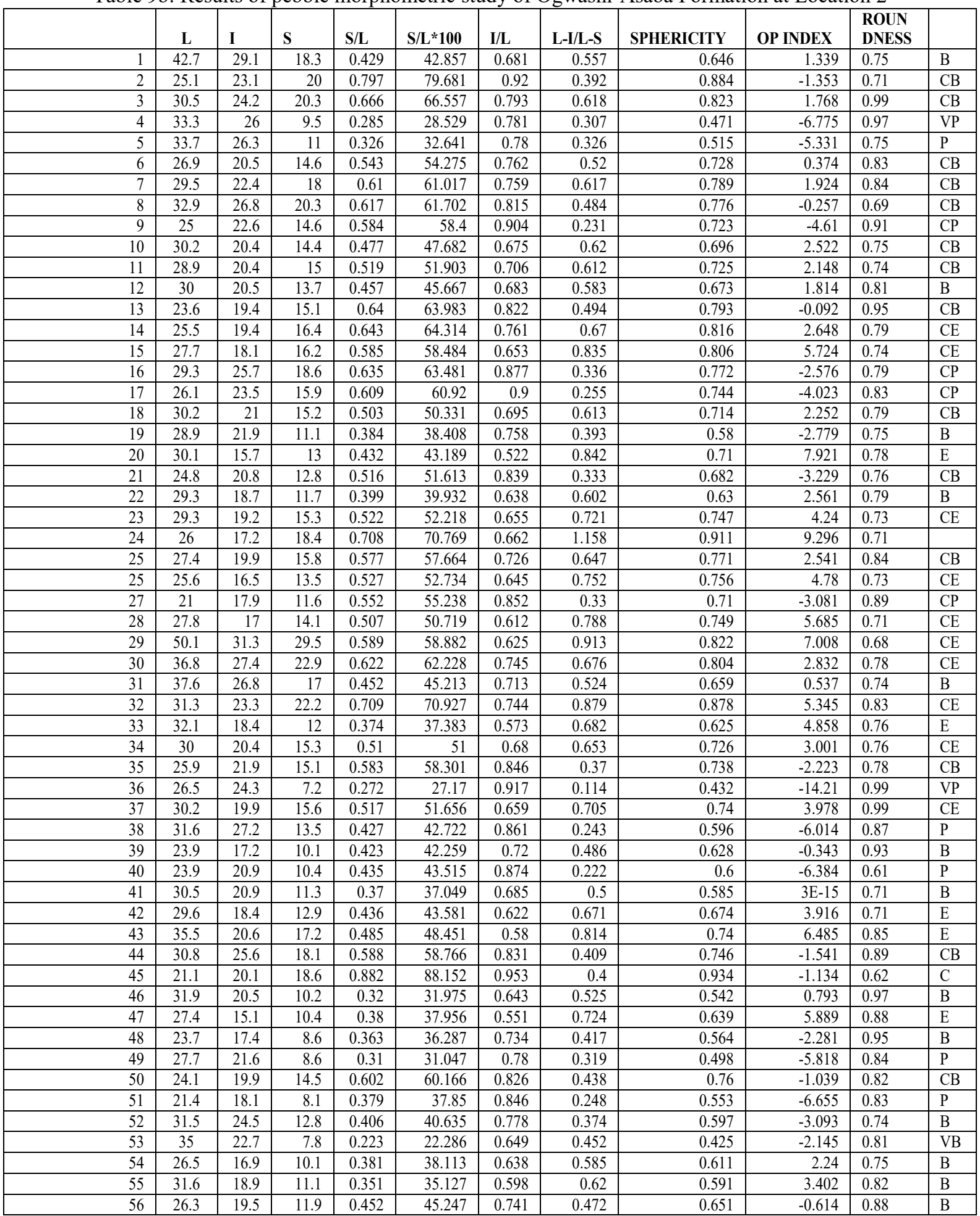




\begin{tabular}{|c|c|c|c|c|c|c|c|c|c|c|c|}
\hline & $\mathbf{L}$ & I & $\mathbf{S}$ & $\mathrm{S} / \mathrm{L}$ & $\mathrm{S} / \mathrm{L} * 100$ & $\mathbf{I} / \mathbf{L}$ & L-I/L-S & SPHERICITY & OP INDEX & $\begin{array}{l}\text { ROUN } \\
\text { DNESS }\end{array}$ & \\
\hline 57 & 27.6 & 20.7 & 10.7 & 0.388 & 38.768 & 0.75 & 0.408 & 0.585 & -2.366 & 0.93 & $\mathrm{~B}$ \\
\hline 58 & 23.3 & 19.3 & 7.7 & 0.33 & 33.047 & 0.828 & 0.256 & 0.509 & -7.371 & 0.97 & $\mathrm{P}$ \\
\hline 59 & 25.1 & 13.6 & 10 & 0.398 & 39.841 & 0.542 & 0.762 & 0.664 & 6.566 & 0.75 & $E$ \\
\hline 60 & 24.1 & 15.8 & 10.8 & 0.448 & 44.813 & 0.656 & 0.624 & 0.674 & 2.768 & 0.85 & $\mathrm{~B}$ \\
\hline 61 & 25.2 & 15.9 & 9.1 & 0.361 & 36.111 & 0.631 & 0.578 & 0.591 & 2.15 & 0.85 & $\mathrm{~B}$ \\
\hline 62 & 25.6 & 18.6 & 15.9 & 0.621 & 62.109 & 0.727 & 0.722 & 0.81 & 3.569 & 0.63 & $\mathrm{CE}$ \\
\hline 63 & 26.4 & 17.4 & 9.1 & 0.345 & 34.47 & 0.659 & 0.52 & 0.565 & 0.587 & 0.71 & $\mathrm{~B}$ \\
\hline 64 & 28.1 & 13.9 & 10.3 & 0.367 & 36.655 & 0.495 & 0.798 & 0.648 & 8.123 & 0.64 & $E$ \\
\hline 65 & 26.6 & 14.9 & 10.4 & 0.391 & 39.098 & 0.56 & 0.722 & 0.649 & 5.684 & 0.73 & $E$ \\
\hline 66 & 31.1 & 14.3 & 11.3 & 0.363 & 36.334 & 0.46 & 0.848 & 0.66 & 9.591 & 0.81 & $E$ \\
\hline 67 & 26.5 & 17.6 & 12.9 & 0.487 & 48.679 & 0.664 & 0.654 & 0.709 & 3.172 & 0.83 & $E$ \\
\hline 68 & 21.4 & 17.3 & 10.9 & 0.509 & 50.935 & 0.808 & 0.39 & 0.685 & -2.15 & 0.62 & $\mathrm{CB}$ \\
\hline 69 & 24.2 & 21.7 & 19 & 0.785 & 78.512 & 0.897 & 0.481 & 0.883 & -0.245 & 0.83 & $\mathrm{C}$ \\
\hline 70 & 22.2 & 19.1 & 10.1 & 0.455 & 45.495 & 0.86 & 0.256 & 0.622 & -5.359 & 0.74 & $\mathrm{P}$ \\
\hline 71 & 26.2 & 19.5 & 10.7 & 0.408 & 40.84 & 0.744 & 0.432 & 0.607 & -1.659 & 0.81 & B \\
\hline 72 & 14.4 & 12.2 & 11.3 & 0.785 & 78.472 & 0.847 & 0.71 & 0.899 & 2.672 & 0.71 & $\mathrm{C}$ \\
\hline 73 & 21.1 & 15.3 & 12.6 & 0.597 & 59.716 & 0.725 & 0.682 & 0.789 & 3.054 & 0.73 & $\mathrm{CE}$ \\
\hline 74 & 21.1 & 15.9 & 10.1 & 0.479 & 47.867 & 0.754 & 0.473 & 0.672 & -0.57 & 0.75 & $\mathrm{~B}$ \\
\hline 75 & 20.9 & 16.1 & 13.4 & 0.641 & 64.115 & 0.77 & 0.64 & 0.811 & 2.184 & 0.93 & CB \\
\hline 76 & 19.6 & 17.8 & 11 & 0.561 & 56.122 & 0.908 & 0.209 & 0.703 & -5.18 & 0.97 & $\mathrm{CP}$ \\
\hline 77 & 27.1 & 17.2 & 11 & 0.406 & 40.59 & 0.635 & 0.615 & 0.638 & 2.831 & 0.73 & B \\
\hline 78 & 26.4 & 19.6 & 11.6 & 0.439 & 43.939 & 0.742 & 0.459 & 0.638 & -0.923 & 0.94 & B \\
\hline 79 & 34.5 & 14.1 & 10 & 0.29 & 28.986 & 0.409 & 0.833 & 0.59 & 11.48 & 0.95 & $\mathrm{VE}$ \\
\hline 80 & 28.6 & 16.5 & 11.4 & 0.399 & 39.86 & 0.577 & 0.703 & 0.651 & 5.105 & 0.87 & $E$ \\
\hline 81 & 20.3 & 14.3 & 8.8 & 0.433 & 43.35 & 0.704 & 0.522 & 0.644 & 0.501 & 0.84 & $\mathrm{P}$ \\
\hline 82 & 25.5 & 18.3 & 11.6 & 0.455 & 45.49 & 0.718 & 0.518 & 0.661 & 0.395 & 0.93 & $\mathrm{~B}$ \\
\hline 83 & 28.8 & 20.4 & 15.1 & 0.524 & 52.431 & 0.708 & 0.613 & 0.729 & 2.158 & 0.89 & $\mathrm{CB}$ \\
\hline 84 & 47.7 & 29.7 & 21.1 & 0.442 & 44.235 & 0.623 & 0.677 & 0.68 & 3.994 & 0.79 & $\mathrm{~B}$ \\
\hline 85 & 28.5 & 19.6 & 16.4 & 0.575 & 57.544 & 0.688 & 0.736 & 0.784 & 4.093 & 0.74 & $\mathrm{CE}$ \\
\hline 86 & 37.9 & 28.4 & 20 & 0.528 & 52.77 & 0.749 & 0.531 & 0.719 & 0.582 & 0.75 & $\mathrm{CB}$ \\
\hline 87 & 48.8 & 29.9 & 22.4 & 0.459 & 45.902 & 0.613 & 0.716 & 0.701 & 4.704 & 0.68 & $E$ \\
\hline 88 & 40.3 & 26.8 & 21.5 & 0.533 & 53.35 & 0.665 & 0.718 & 0.754 & 4.088 & 0.68 & $\mathrm{CE}$ \\
\hline 89 & 38.6 & 25.4 & 20.9 & 0.541 & 54.145 & 0.658 & 0.746 & 0.764 & 4.539 & 0.78 & $\mathrm{CE}$ \\
\hline 90 & 32 & 25.2 & 20.8 & 0.65 & 65 & 0.788 & 0.607 & 0.813 & 1.648 & 0.72 & $\mathrm{CB}$ \\
\hline 91 & 41.6 & 25 & 17 & 0.409 & 40.865 & 0.601 & 0.675 & 0.653 & 4.277 & 0.85 & $E$ \\
\hline 92 & 44.4 & 27.1 & 23.9 & 0.538 & 53.829 & 0.61 & 0.844 & 0.78 & 6.389 & 0.64 & $\mathrm{CE}$ \\
\hline 93 & 20.9 & 17.5 & 13.8 & 0.66 & 66.029 & 0.837 & 0.479 & 0.804 & -0.32 & 0.85 & $\mathrm{CB}$ \\
\hline 94 & 37.7 & 26.1 & 23.6 & 0.626 & 62.599 & 0.692 & 0.823 & 0.827 & 5.155 & 0.68 & $\mathrm{CE}$ \\
\hline 95 & 28 & 22.1 & 13.5 & 0.482 & 48.214 & 0.789 & 0.407 & 0.665 & -1.931 & 0.95 & B \\
\hline 96 & 36.3 & 21.9 & 14.8 & 0.408 & 40.771 & 0.603 & 0.67 & 0.651 & 4.164 & 0.77 & $E$ \\
\hline 97 & 23.1 & 19.5 & 14.1 & 0.61 & 61.039 & 0.844 & 0.4 & 0.761 & -1.638 & 0.84 & $\mathrm{CB}$ \\
\hline 98 & 38.4 & 17.8 & 16 & 0.417 & 41.667 & 0.464 & 0.92 & 0.721 & 10.07 & 0.77 & $E$ \\
\hline 99 & 53.2 & 32.2 & 20.6 & 0.387 & 38.722 & 0.605 & 0.644 & 0.628 & 3.723 & 0.79 & B \\
\hline 100 & 41.6 & 34.2 & 26.8 & 0.644 & 64.423 & 0.822 & 0.5 & 0.796 & $-2 \mathrm{E}-15$ & 0.68 & $\mathrm{CB}$ \\
\hline 101 & 29.9 & 19.5 & 15.5 & 0.518 & 51.839 & 0.652 & 0.722 & 0.744 & 4.287 & 0.75 & $\mathrm{CE}$ \\
\hline 102 & 26.1 & 21.5 & 16.6 & 0.636 & 63.602 & 0.824 & 0.484 & 0.789 & -0.248 & 0.78 & $\mathrm{CB}$ \\
\hline 103 & 30.9 & 17.8 & 15 & 0.485 & 48.544 & 0.576 & 0.824 & 0.742 & 6.672 & 0.96 & $E$ \\
\hline 104 & 25.6 & 17.7 & 15.7 & 0.613 & 61.328 & 0.691 & 0.798 & 0.816 & 4.859 & 0.72 & $\mathrm{CE}$ \\
\hline 105 & 31.6 & 15 & 14 & 0.443 & 44.304 & 0.475 & 0.943 & 0.745 & 10 & 0.73 & $E$ \\
\hline 106 & 36.9 & 20.9 & 18.1 & 0.491 & 49.051 & 0.566 & 0.851 & 0.752 & 7.157 & 0.68 & $E$ \\
\hline 107 & 30.2 & 21.3 & 16.7 & 0.553 & 55.298 & 0.705 & 0.659 & 0.757 & 2.88 & 0.63 & $E$ \\
\hline 108 & 31.3 & 21.6 & 14.1 & 0.45 & 45.048 & 0.69 & 0.564 & 0.665 & 1.42 & 0.73 & B \\
\hline 109 & 42.5 & 25.5 & 18.8 & 0.442 & 44.235 & 0.6 & 0.717 & 0.688 & 4.912 & 0.96 & $E$ \\
\hline 110 & 30.6 & 23.9 & 14.5 & 0.474 & 47.386 & 0.781 & 0.416 & 0.66 & -1.77 & 0.68 & B \\
\hline 111 & 35.3 & 20.5 & 17.7 & 0.501 & 50.142 & 0.581 & 0.841 & 0.756 & 6.799 & 0.74 & $\mathrm{CE}$ \\
\hline 112 & 64.6 & 35.3 & 16.1 & 0.249 & 24.923 & 0.546 & 0.604 & 0.484 & 4.178 & 0.65 & $\mathrm{VB}$ \\
\hline 113 & 32.7 & 27.3 & 23.1 & 0.706 & 70.642 & 0.835 & 0.563 & 0.842 & 0.885 & 0.64 & $\mathrm{C}$ \\
\hline 114 & 25.4 & 18.2 & 14.3 & 0.563 & 56.299 & 0.717 & 0.649 & 0.762 & 2.64 & 0.68 & $\mathrm{CE}$ \\
\hline 115 & 32.4 & 16.7 & 11.6 & 0.358 & 35.802 & 0.515 & 0.755 & 0.629 & 7.117 & 0.74 & $E$ \\
\hline 116 & 21 & 14.5 & 12.7 & 0.605 & 60.476 & 0.69 & 0.783 & 0.809 & 4.682 & 0.88 & $\mathrm{CE}$ \\
\hline 117 & 25.7 & 17.6 & 13 & 0.506 & 50.584 & 0.685 & 0.638 & 0.72 & 2.724 & 0.73 & $\mathrm{CB}$ \\
\hline 118 & 34.2 & 19.1 & 17.2 & 0.503 & 50.292 & 0.558 & 0.888 & 0.768 & 7.72 & 0.85 & $\mathrm{CE}$ \\
\hline 119 & 34.2 & 19.8 & 14.5 & 0.424 & 42.398 & 0.579 & 0.731 & 0.677 & 5.448 & 0.78 & $E$ \\
\hline 120 & 36.5 & 20.7 & 15.5 & 0.425 & 42.466 & 0.567 & 0.752 & 0.683 & 5.943 & 0.63 & $E$ \\
\hline 121 & 32.7 & 18 & 15.1 & 0.462 & 46.177 & 0.55 & 0.835 & 0.729 & 7.26 & 0.88 & $E$ \\
\hline 122 & 33.8 & 18.5 & 15.4 & 0.456 & 45.562 & 0.547 & 0.832 & 0.724 & 7.276 & 0.77 & $E$ \\
\hline 123 & 36.1 & 17.9 & 17 & 0.471 & 47.091 & 0.496 & 0.953 & 0.765 & 9.617 & 0.95 & $E$ \\
\hline 124 & 29.3 & 12.5 & 10 & 0.341 & 34.13 & 0.427 & 0.87 & 0.649 & 10.85 & 0.68 & $E$ \\
\hline
\end{tabular}




\begin{tabular}{|c|c|c|c|c|c|c|c|c|c|c|c|}
\hline & $\mathbf{L}$ & I & $\mathbf{S}$ & $\mathrm{S} / \mathrm{L}$ & $\mathrm{S} / \mathrm{L} * \mathbf{1 0 0}$ & $\mathbf{I} / \mathbf{L}$ & L-I/L-S & SPHERICITY & OP INDEX & $\begin{array}{l}\text { ROUN } \\
\text { DNESS }\end{array}$ & \\
\hline 125 & 30.6 & 21.5 & 20.4 & 0.667 & 66.667 & 0.703 & 0.892 & 0.858 & 5.882 & 0.78 & $\mathrm{CE}$ \\
\hline 126 & 24 & 18.7 & 17.5 & 0.729 & 72.917 & 0.779 & 0.815 & 0.88 & 4.325 & 0.87 & $\mathrm{C}$ \\
\hline 127 & 29.1 & 17 & 13 & 0.447 & 44.674 & 0.584 & 0.752 & 0.699 & 5.631 & 0.95 & $E$ \\
\hline 128 & 34.5 & 18.5 & 15.1 & 0.438 & 43.768 & 0.536 & 0.825 & 0.71 & 7.42 & 0.71 & $E$ \\
\hline 129 & 29.5 & 14.1 & 12.5 & 0.424 & 42.373 & 0.478 & 0.906 & 0.722 & 9.579 & 0.63 & $E$ \\
\hline 130 & 29.1 & 22.1 & 19.5 & 0.67 & 67.01 & 0.759 & 0.729 & 0.839 & 3.42 & 0.68 & $E$ \\
\hline 131 & 29.3 & 19 & 15.2 & 0.519 & 51.877 & 0.648 & 0.73 & 0.746 & 4.443 & 0.77 & $\mathrm{CB}$ \\
\hline 132 & 25.8 & 23.1 & 20.5 & 0.795 & 79.457 & 0.895 & 0.509 & 0.89 & 0.119 & 0.77 & $\mathrm{C}$ \\
\hline 133 & 30.7 & 17.3 & 15.9 & 0.518 & 51.792 & 0.564 & 0.905 & 0.781 & 7.828 & 0.87 & $\mathrm{CE}$ \\
\hline 134 & 31 & 18 & 11.2 & 0.361 & 36.129 & 0.581 & 0.657 & 0.608 & 4.334 & 0.61 & $E$ \\
\hline 135 & 30.6 & 17.8 & 15 & 0.49 & 49.02 & 0.582 & 0.821 & 0.745 & 6.538 & 0.75 & $E$ \\
\hline 136 & 25.7 & 14.7 & 18.3 & 0.712 & 71.206 & 0.572 & 1.486 & 0.961 & 13.85 & 0.95 & \\
\hline 137 & 27.5 & 17.5 & 15.3 & 0.556 & 55.636 & 0.636 & 0.82 & 0.786 & 5.746 & 0.87 & $\mathrm{CE}$ \\
\hline 138 & 23.5 & 19.3 & 14.2 & 0.604 & 60.426 & 0.821 & 0.452 & 0.763 & -0.801 & 0.78 & $\mathrm{CB}$ \\
\hline 139 & 24.7 & 17.4 & 8.5 & 0.344 & 34.413 & 0.704 & 0.451 & 0.552 & -1.435 & 0.85 & B \\
\hline 140 & 27.6 & 16.5 & 14 & 0.507 & 50.725 & 0.598 & 0.816 & 0.755 & 6.233 & 0.77 & $\mathrm{CE}$ \\
\hline 141 & 27.3 & 16.2 & 12.5 & 0.458 & 45.788 & 0.593 & 0.75 & 0.707 & 5.46 & 0.87 & $E$ \\
\hline 142 & 28 & 18 & 12.1 & 0.432 & 43.214 & 0.643 & 0.629 & 0.662 & 2.984 & 0.75 & B \\
\hline 143 & 26 & 17 & 13.4 & 0.515 & 51.538 & 0.654 & 0.714 & 0.741 & 4.158 & 0.88 & $\mathrm{CE}$ \\
\hline 144 & 29.2 & 15 & 14 & 0.479 & 47.945 & 0.514 & 0.934 & 0.765 & 9.056 & 0.66 & $E$ \\
\hline 145 & 25.7 & 17.8 & 16.7 & 0.65 & 64.981 & 0.693 & 0.878 & 0.848 & 5.814 & 0.83 & $\mathrm{CE}$ \\
\hline 146 & 24.4 & 14 & 12 & 0.492 & 49.18 & 0.574 & 0.839 & 0.75 & 6.887 & 0.63 & $E$ \\
\hline 147 & 27.8 & 13.8 & 10.5 & 0.378 & 37.77 & 0.496 & 0.809 & 0.66 & 8.188 & 0.87 & $E$ \\
\hline 148 & 27.5 & 13.2 & 9 & 0.327 & 32.727 & 0.48 & 0.773 & 0.607 & 8.341 & 0.66 & $\mathrm{E}$ \\
\hline 149 & 24 & 13.5 & 10 & 0.417 & 41.667 & 0.563 & 0.75 & 0.676 & 6 & 0.87 & $E$ \\
\hline 150 & 28.3 & 19.3 & 16.9 & 0.597 & 59.717 & 0.682 & 0.789 & 0.806 & 4.847 & 0.71 & $\mathrm{CE}$ \\
\hline Mean & 29.72 & 20.1 & 14.58 & 0.498 & 49.779 & 0.686 & 0.631 & 0.709 & 2.605 & 0.8046 & B \\
\hline Standard Deviation & 6.776 & 4.41 & 4.079 & 0.121 & 12.144 & 0.118 & 0.206 & 0.1 & 4.4 & 0.0976 & \\
\hline
\end{tabular}

